\title{
Microbiological Quality of Seawater and Mussels (Mytilus galloprovincialis, Lamarck 1819) in the Dubrovnik Coastal Area (Southeastern Adriatic)
}

\section{Mikrobiološka kvaliteta morske vode i dagnje (Mytilus galloprovincialis, Lamarck 1819) u priobalju Dubrovnika (jugoistočni Jadran)}

\author{
Svjetlana Bobanović-Ćolić \\ University of Dubrovnik \\ Institute for Marine and Coastal Research \\ E-mail: svjetlana.bobanovic-colic@unidu.hr
}

\author{
Jakša Bolotin \\ University of Dubrovnik \\ Institute for Marine and Coastal Research \\ E-mail: jaksa.bolotin@unidu.hr
}

\author{
Nikša Glavić \\ University of Dubrovnik \\ Institute for Marine and Coastal Research \\ E-mail: niksa.glavic@unidu.hr
}

\author{
Enis Hrustić \\ Ruđer Bošković Institute \\ Centre for Marine Research \\ E-mail: hrustic.enis@gmail.com
}

Summary

This research was conducted between March 2016 and March 2017 as the first study on the water and mussel quality in the coastal area of Dubrovnik (Croatia). Bacteriological analyses were conducted simultaneously on wild mussels (Mytilus galloprovincialis) tissue and their ambient water. The total numbers of heterotrophic bacteria, total coliforms, faecal coliforms and faecal streptococci in the water were determined. Concentrations of Escherichia coli were measured in mussel. The investigated stations are located in coastal water, which is particularly influenced by climatic and anthropogenic factors interacting at the boundaries between the land and freshwater and seawater environments. Seasonal variables, such as rainfall and riverine network characteristics, determine the delivery of bacteria (including $E$. coli) to coastal water. Direct methods of assessing the density of heterotrophic bacteria at all sampling stations showed the characteristics of an oligotrophic area. The abundance of faecal coliform bacteria was in all cases higher within mussel tissue than in the surrounding water where levels were sometimes undetectable. Maximum $E$. coli concentrations in mussels and seawater were regularly recorded through the summer, with the exceptions of April 2016 and January 2017 at two stations following precipitation. Minimum faecal coliform concentrations were recorded in the winter.

\section{Sažetak}

U razdoblju od ožujka 2016. do ožujka 2017. u obalnom području Dubrovnika (Hrvatska) prvi put je provedena bakteriološka analiza kvalitete vode i tkiva prirodnih populacija mediteranske dagnje (Mytilus galloprovincialis). U morskoj vodi praćen je ukupan broj heterotrofnih bakterija, ukupnih koliforma, fekalnih koliforma i fekalnih streptokoka. U tkivu i intervalvalnoj tekućini školjkaša mjerena je koncentracija bakterije Escherichia coli. Istraživane su postaje u obalnoj zoni djelomično pod utjecajem klimatskih i antropogenih čimbenika. Sezonske promjene u protoku rijeke i količini oborina uvjetuju ukupnu količinu bakterija (između njih i E. coli) u obalnom moru. Direktna metoda brojanja heterotrofnih bakterija na svim istraživanim postajama pokazala je da se radi o oligotrofnom području. Broj bakterija fekalnih koliforma veći je u tkivu školjkaša, nego u okolnoj vodi, gdje su razine ponekad bile neprimjetne. Najveće koncentracije E. coli u školjkama i morskoj vodi zabilježene su ljeti, ali i, zbog povećanih količina oborina, u travnju 2016. i siječnju 2017. god. na dvije postaje. Minimalne koncentracije fekalnih koliforma zabilježene su zimi.
DOI 10.17818/NM/2021/3.1

UDK 551.464.3:594.1(262.3)

Original scientific paper / Izvorni znanstveni rad Paper accepted / Rukopis primljen: 14. 8. 2020.

\section{KEY WORDS}

heterotrophic bacteria

total coliforms

faecal coliforms

faecal streptococci

Mytilus galloprovincialis

Escherichia coli

Dubrovnik

Southeastern Adriatic

\section{INTRODUCTION / Uvod}

Coastal water where the land and freshwater meet is particularly influenced by environmental, climatic and anthropogenic factors. Seawater quality is important for both local habitants and tourists. Seasonal variables, such as rainfall $[13,17]$, sea and air temperature and river flow, determine delivery of the bacteria to coastal waters [7]. Also, seasonal changes in numbers of the human population, which increases considerably during summer, can influence these parameters [18, 11, 33]. Numerous human activities in this area, such as urbanization, increased marine traffic and numerous swimmers, also influence the intensity of pollution. Faecal indicator bacteria identified in water are generally derived from either human and/or animal sources. Also some highly significant and variable influences on faecal pollution in the aquatic environment of the Dubrovnik 
area can come from the combined outflows of untreated sewage in the city area, the inflow of nutrients, occasional runoff from streets, city wall and land, and septic tanks that leak into the karst geology. The observation of concentration of Escherichia coli measured in Mytilus galloprovincialis tissue is an additional indicator of microbial pollution [6, 9]. On the basis of existing literature [31, 9] Mytilus galloprovincialis is a good representative of the sampling area because it is a sedentary filter-feeder and a widely distributed species that concentrates and retains human pathogens present in the areas where it grows. Faecal indicator bacteria are a potential hazard to the health of swimmers and other consumers.

This is the first study conducted on the seawater and mussel quality of the Dubrovnik coastal area. To investigate the ecology of coastal waters six microbiological parameters were used: the total number of heterotrophic bacteria, cultivated heterotrophic bacteria, total coliforms, faecal coliforms, faecal streptococci and concentrations of Escherichia coli measured in Mytilus galloprovincialis tissue. Bacteria are rapid indicators of the ecological status of coastal waters and concentrations of nutrients and microbiological pollution [20]. Assessments were determined on the basis of criteria defined by the Croatian national standards [24] and the EU Directive on the management of bathing water quality No 2006/7/EC [23]. Concentration of $E$. coli is the indicator of the quality of shellfish and it is used to classify the waters [1].

\section{MATERIAL AND METHODS / Materijal i metode 2.1. Study area / Područje istraživanja}

This research was conducted at five stations in the broader mediolittoral area of the City of Dubrovnik. Two sampling stations were located in the urban city area ( $P-1$ the Old City port in the vicinity of a rainwater outlet; P-2 in the bay of Gruž), two in the estuary of the river Ombla (P-3 and $P-4)$ and one in Trsteno (P-5) (Figure 1).
The Old City of Dubrovnik has 2128 inhabitants [26]. The main city sewage system, dating from 1436, originally had two directions of flow, one toward the east and city harbour and one toward the west, with the outflow beneath the Bokar fort. Since 2004 the entire system has been routed through a main purifying plant at the foot of Petka hill which is now the main Dubrovnik outflow. In the investigated area there are no exclusively sewage outflows, but only ones partially connected to storm drains. Station P-1 is in the immediate vicinity of a storm drain outflow.

Station P-2 in bay of Gruž is within the main Dubrovnik passenger and commercial harbour. Dubrovnik harbour in 2016 received a total of 556 cruise ships with 799,916 passengers and 1,976,000 overnights from cruise ships (Dubrovnik Port Authority). The bay of Gruž is under the influence of the river Ombla, the open waters of the southern Adriatic and a strong anthropogenic pressure. There are no sewage outflows in the vicinity of the bay of Gruž. The greater Dubrovnik area, with a population of 28,113 inhabitants [26], is connected to the main sewage underwater outflow. The city of Dubrovnik recorded 2,942,422 overnights (TZ-Tourist board) in 2016 with the majority of tourist arrivals during the summer months.

This study was also conducted in the highly stratified Ombla Estuary, near the city of Dubrovnik. It is in a zone of karst source waters and is in contact with Adriatic seawater, combined with an increasing anthropogenic influence during the summer tourist season. The Ombla Estuary has been recognized under the Croatian Law of Nature Protection as a significant national resource. In its lower part the estuary is connected with the bay of Gruž. An outflow of sewage water, which serves the surrounding settlements, is situated in the middle of the estuary. A new sewage system was opened in July 2015, but, since it does not connect all households, some of them still release sewage water directly into the estuary. The flow and influx of the river Ombla is the major factor influencing the environment. The measured flow of the river Ombla at the source was 4-109 $\mathrm{m}^{3} \mathrm{~s}^{-1}$ over a period

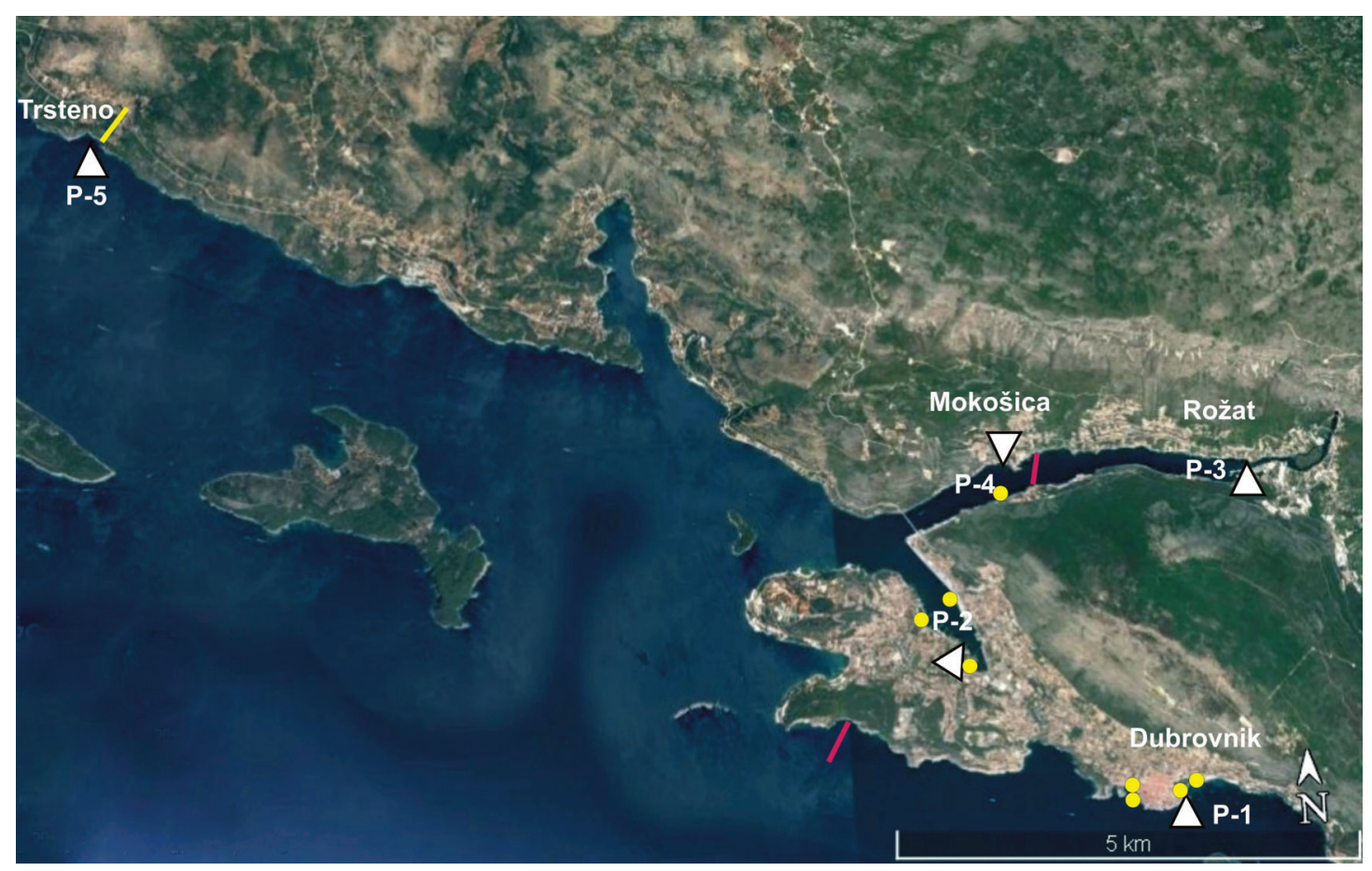

Figure 1 Study area (Dubrovnik, Southern Adriatic Sea) and sampling sites (yellow dots - storm drain outflow, red marks - sewage) Slika 1. Područje istraživanja (Dubrovnik, jugoistočni Jadran) i istraživane postaje (žute oznake - odvodi oborinskih voda, crvene oznake - kanalizacija) 
of 30 years $(1962$ - 1990), with an annual average of 21.63 $\mathrm{m}^{3} \mathrm{~s}^{-1}$ [4]. Besides river flow, surface rainfall that drains into the estuary from a large catchment area $\left(800-900 \mathrm{~km}^{2}\right)$ has a strong influence on the water [4]. Samples from the estuary were taken at two sites, P-3 at Rožat (upper estuary) and P-4 in Mokošica (lower estuary) at some distance from storm and sewage waters outlets (Figure 1). The right bank of the estuary has a population of 2,331 and the entire estuary area 2,997 inhabitants $(9,106$ with new settlements) [26]. The number of tourists during 2016 was 32,773 on the right bank and 41,127 for the entire estuary (Dubrovnik Tourist Board). In its upper part, the estuary holds a yacht marina with 380 berths and a small shipyard while the main activity of the area is tourism with one hostel and numerous apartment houses.

Sampling station P-5 in located in the village of Trsteno (Figure 1) with 222 inhabitants [26]. The population of Trsteno increases considerably during the tourist season. The tourist board recorded 7,998 tourists for 2016, with numerous day excursionists. At the sampling site there is a creek that passes through the village and discharges into the sea. It never runs dry and along with a lot of private in-ground septic systems it is a major source of faecal pollution.

\subsection{Methods / Metode}

The research was conducted between March 2016 and March 2017, six times a year at five stations, in the coastal area of Dubrovnik (Croatia). Before every sampling, the temperature (ST) and salinity (Sal) of the ambient (overlying) water were measured at each station using a WTW Multiline P4 multiparameter probe. The Meteorological and Hydrological Service data on air temperature and the amount of daily rainfall were used for the city of Dubrovnik.

Water samples were collected at $0.30 \mathrm{~m}$ depth at each station using sterilized glass bottles that were stored in the dark inside portable cool boxes during transport to the laboratory. Seawater samples for direct counting were immediately fixed with formaldehyde at a total concentration of $2 \%$ (vol./ vol.). At station $\mathrm{P}-5$ there is a creek discharging into the sea, whose water was tested twice, in January and March 2017.

The total number of heterotrophic bacteria was determined using a direct counting method under epifluorescent microscopy [14]. All samples were analysed within five days, and until processing were stored in the dark in a refrigerator at a temperature of about $5^{\circ} \mathrm{C}$. For bacteria colouring a $0.01 \%$ solution of acridine orange was used and the $10 \mathrm{~mL}$ subsamples were filtered through Nucleopore filters (pore diameter of $0.2 \mu \mathrm{m}$ ). Bacterial cells were counted

Table 1 Abiotic parameters measured at the various sampling sites Tablica 1. Abiotički parametri izmjereni na istraživanim postajama

\begin{tabular}{|c|c|c|c|c|c|}
\hline Station & Date & $\begin{array}{l}\text { Air temperature } \\
\qquad\left({ }^{\circ} \mathrm{C}\right)\end{array}$ & $\begin{array}{l}\text { Daily rainfall } \\
\qquad(\mathrm{mm})\end{array}$ & $\begin{array}{l}\text { Sea water temperature } \\
\qquad\left({ }^{\circ} \mathrm{C}\right)\end{array}$ & $\begin{array}{l}\text { Salinity } \\
\text { (psu) }\end{array}$ \\
\hline \multirow{7}{*}{$P-1$} & 31.03 .2016 & 17.7 & 0.0 & 14.1 & 31.27 \\
\hline & 25.04 .2016 & 14.0 & 5.6 & 15.7 & 32.57 \\
\hline & 7.07.2016 & 25.0 & 0.0 & 23.5 & 35.97 \\
\hline & 15.09 .2016 & 26.7 & 0.0 & 24.0 & 37.37 \\
\hline & 14.11.2016 & 13.8 & 0.0 & 17.4 & 38.27 \\
\hline & 12.01 .2017 & 4.3 & 1.4 & 10.8 & 37.67 \\
\hline & 14.03 .2017 & 15.7 & 0.0 & 13.9 & 38.40 \\
\hline \multirow{6}{*}{ P-2 } & 6.04 .2016 & 18.8 & 0.0 & 17.0 & 32.77 \\
\hline & 13.07.2016 & 28.1 & 0.0 & 26.0 & 34.77 \\
\hline & 16.09.2016 & 26.6 & 0.0 & 23.8 & 38.77 \\
\hline & 15.11 .2016 & 9.5 & 0.0 & 13.7 & 34.27 \\
\hline & 10.01.2017 & -3.7 & 0.0 & 9.0 & 37.37 \\
\hline & 15.03 .2017 & 13.3 & 0.0 & 14.0 & 37.37 \\
\hline \multirow{6}{*}{ P-3 } & 8.04.2016 & 20.1 & 0.0 & 14.8 & 14.97 \\
\hline & 11.07 .2016 & 28.5 & 0.0 & 20.3 & 12.37 \\
\hline & 21.09 .2016 & 22.0 & 0.0 & 22.4 & 30.77 \\
\hline & 11.11 .2016 & 16.4 & 8.3 & 15.7 & 13.77 \\
\hline & 9.01 .2017 & -0.3 & 0.0 & 13.6 & 10.17 \\
\hline & 17.03 .2017 & 17.3 & 0.0 & 14.9 & 38.77 \\
\hline \multirow{6}{*}{ P-4 } & 8.04.2016 & 20.1 & 0.0 & 15.7 & 19.67 \\
\hline & 11.07 .2016 & 28.5 & 0.0 & 9.1 & 17.70 \\
\hline & 21.09 .2016 & 22.0 & 0.0 & 22.3 & 35.57 \\
\hline & 11.11 .2016 & 16.4 & 8.3 & 15.5 & 17.67 \\
\hline & 9.01 .2017 & -0.3 & 0.0 & 10.3 & 26.67 \\
\hline & 17.03 .2017 & 16.5 & 0.0 & 12.6 & 15.37 \\
\hline \multirow{6}{*}{ P-5 } & 5.05 .2016 & 21.5 & 0.4 & 16.7 & 35.37 \\
\hline & 6.07 .2016 & 28.2 & 0.0 & 24.9 & 36.87 \\
\hline & 20.09 .2016 & 24.2 & 3.0 & 23.2 & 38.77 \\
\hline & 9.11 .2016 & 15.3 & 10.3 & 19.7 & 37.67 \\
\hline & 16.01 .2017 & 7.2 & 0.0 & 13.4 & 38.90 \\
\hline & 16.03.2017 & 17.1 & 0.0 & 13.5 & 36.27 \\
\hline
\end{tabular}



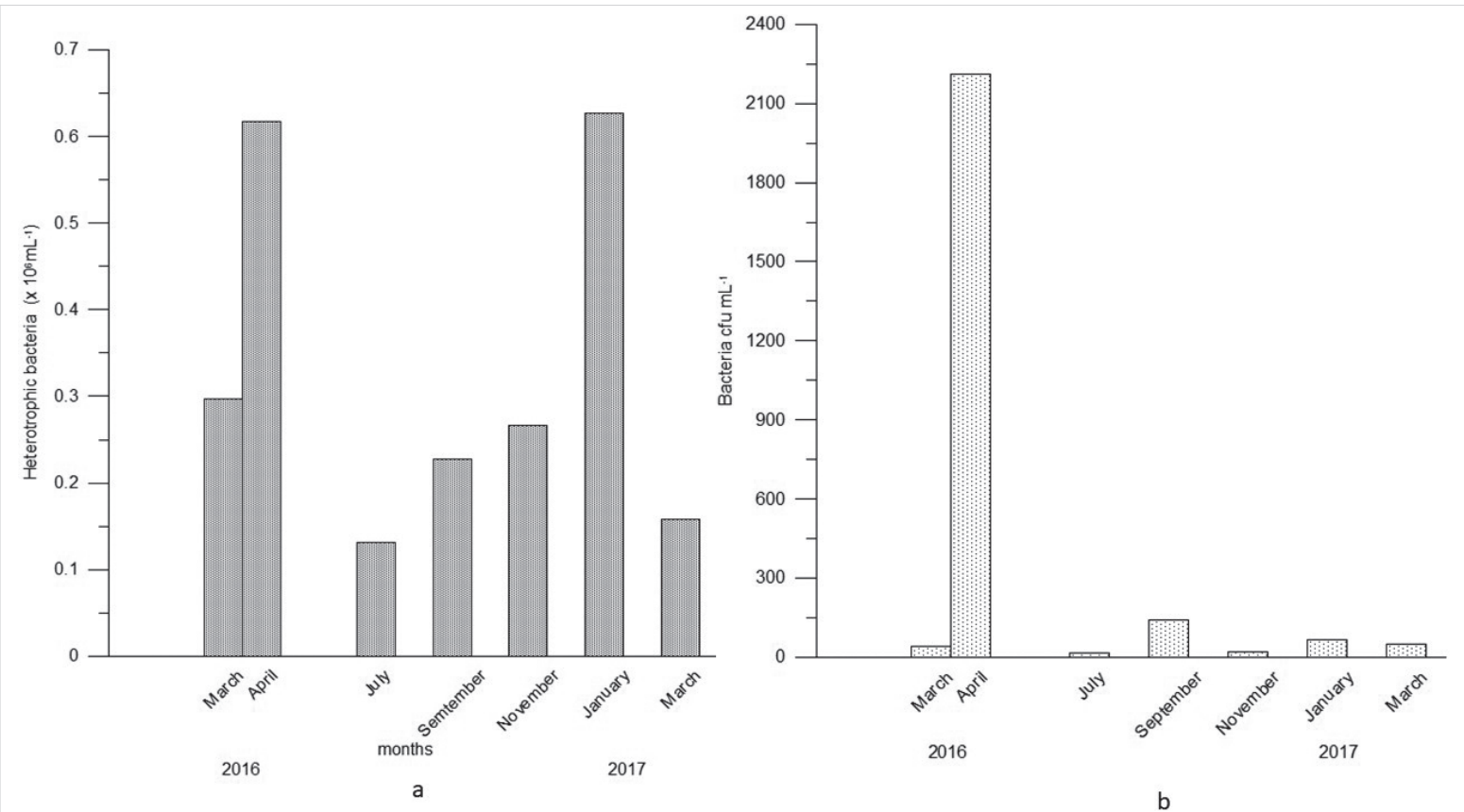

Figure 2 Heterotrophic bacterial abundances in the water (Station P-1): a) total - epifluorescent microscopy method, b) culturable - Spread Plate Method

Slika 2. Broj heterotrofnih bakterija u uzorcima morske vode (postaja P-1): a) ukupni broj metodom epifluorescentne mikroskopije, b) broj kolonija metodom širenja razmaza

using a Jenalumar Zeiss fluorescent microscope under $1500 \mathrm{x}$ magnification. To count the culturable heterotrophic bacteria the direct method of cultivation was used. The samples of $0.1 \mathrm{~mL}$ were inoculated by spreading on plates using a sterile L-shaped glass spreader on Reasoner's agar (R2A agar, Biolife, Italy). The number of bacteria was determined as the number of colonyforming cells (colony forming unit, CFU) per $\mathrm{ml}$ after 10 days of incubation at room temperature.

To determine the quantity of bacterial indicators of sanitary quality, total coliforms, faecal coliforms and faecal streptococci in water, subsamples of 10 and $100 \mathrm{~mL}$ were membrane filtered and the filters subsequently incubated on a plate with a culture medium of M-Endo Agar at $36^{\circ} \mathrm{C}$ for $24 \mathrm{~h}, \mathrm{~m}$-Faecal Coliform agar at $44.5^{\circ} \mathrm{C}$ for $24 \mathrm{~h}$ and Slanetz-Bartley agar (Biolife, Italy) at $36^{\circ} \mathrm{C}$ for $48 \mathrm{~h}[34,35,36]$. The station $\mathrm{P}-1$ in previous research showed faecal pollution (unpublished data). Because of high values bacteria expectations for this station were additionally membrane filtered subsamples of $1 \mathrm{~mL}$. Concentrations are expressed as colony-forming units (CFU) $100 \mathrm{~mL}^{-1}$ of the sample.

Live mussels were collected at the same locations and at the same time as the water samples; 10 individuals were sampled per location, and brought to laboratory without any water medium in order to preserve the intravalvular liquid for analysis. The microbiological study of mussels involved the fivetube Most Probable Number (MPN), one of the methods for the determination of Escherichia coli (EC) [37]. Each sample was comprised of 10 mussels from the same batch. The mussels were rinsed under cold running tap water to remove any sediment and biofouling. The shells were aseptically opened with a sterile knife. Tissue and intravalvular liquids (FIL) were collected, weighed and diluted with peptone water. The mixture was homogenised and diluted to decimal dilutions. The inoculated

Table 2 Correlation of parameters (Station P-1)

Tablica 2. Korelacije istraživanih parametara (postaja P-1)

\begin{tabular}{|c|c|c|c|c|c|c|c|c|c|c|}
\hline & TEMP & $\mathrm{KO}$ & ST & SAL & $\mathrm{BACT}$ & $\mathrm{TC}$ & $\mathrm{FC}$ & FS & $\mathrm{R} 2 \mathrm{a}$ & MPN \\
\hline TEMP & 1,00 & & & & & & & & & \\
\hline $\mathrm{KO}$ & $-0,45$ & 1,00 & & & & & & & & \\
\hline ST & 0,85 & $-0,36$ & 1,00 & & & & & & & \\
\hline SAL & $-0,18$ & $-0,37$ & 0,10 & 1,00 & & & & & & \\
\hline BACT & $-0,74$ & $0,86 *$ & $-0,61$ & $-0,30$ & 1,00 & & & & & \\
\hline $\mathrm{TC}$ & $-0,01$ & $0,77^{*}$ & 0,14 & $-0,52$ & 0,54 & 1,00 & & & & \\
\hline FC & $-0,16$ & $0,94 * *$ & $-0,09$ & $-0,34$ & 0,66 & $0,83^{*}$ & 1,00 & & & \\
\hline FS & 0,13 & 0,73 & 0,14 & $-0,50$ & 0,54 & 0,70 & $0,83^{*}$ & 1,00 & & \\
\hline $\mathrm{R} 2 \mathrm{a}$ & $-0,10$ & $0,86^{*}$ & $-0,12$ & $-0,41$ & 0,66 & 0,63 & $0,91 * *$ & $0,93^{* *}$ & 1,00 & \\
\hline MPN & 0,29 & 0,53 & 0,54 & $-0,35$ & 0,26 & $0,85^{* *}$ & 0,64 & 0,66 & 0,50 & 1,00 \\
\hline
\end{tabular}

Correlation values between parameters measured.Station-1

Correlation are statisticaly significant $\mathrm{P}<0,01\left(^{(*)}\right.$ and $\mathrm{P}<0,05\left(^{*}\right)$.

TEMP, air temperature; $\mathrm{KO}$, daily rainfall; $\mathrm{ST}$ sea temperature; $\mathrm{SAL}$, salinity; $\mathrm{BACT}$, bacterioplankton ; TC, total coliforms; FC, faecal coliforms; FS, faecal streptococci; R2a viable heterotrophic bacteria; MPN mussells E.coli. 


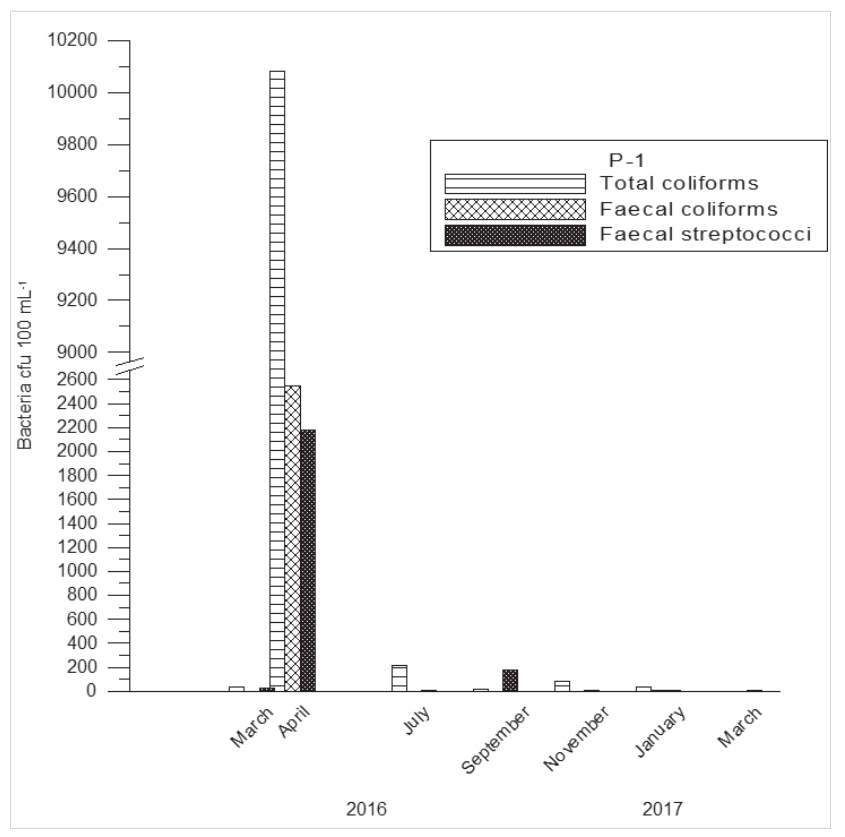

Figure 3 Results of total, faecal coliforms and faecal streptococci counts in the water samples (Station P-1) Slika 3. Broj ukupnih i fekalnih koliforma i fekalnih streptokoka u morskoj vodi (postaja P-1)

tubes with inverted Durham's tubes with MacConkey broth (Biolife, Italy) were incubated at $37^{\circ} \mathrm{C}$ for $48 \mathrm{~h}$. Tubes that were positive for both acid and gas production were subcultured and incubated in Tryptone water at $44^{\circ} \mathrm{C}$ for $24 \mathrm{~h}$. Indole formation was demonstrated by adding two or three drops of Kovacs reagent. Development of a pinkish-red colour indicated a positive test and confirmed EC presence. The MPN was determined from standard tables. All mussel and ambient water samples were analysed within 2 hours of collection.

\subsection{Statistical analysis / Statistika}

Statistical analysis was performed by using the Statsoft Statistica v. 7.0. The groups of data were tested for normality of distribution (Shapiro-Wilks W test). Statistically significant differences between the two survey groups of measurements and between individual parameters were determined by pairwise Student t-test (Microsoft Excel, Microsoft) on logarithmically transformed data $(\log (x+1))$.

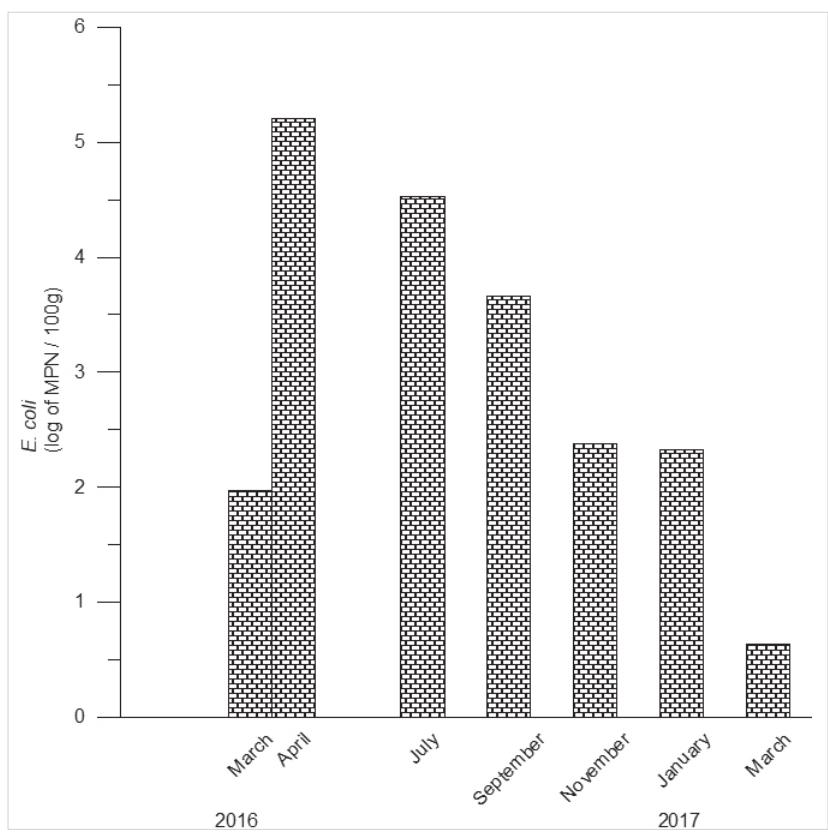

Figure 4 Concentration of $E$. coli in the mussel samples (Station P-1) Slika 4. Koncentracija E. coli u tkivu školjkaša (postaja P-1)

\section{RESULTS / Rezultati}

The values of the meteorological and hydrological measurements during the samplings are recorded in Table 1. During the sampling period the minimum air temperature was $-3.7^{\circ} \mathrm{C}$ and the maximum being $28.5^{\circ} \mathrm{C}$. Minimum sea water temperature was $9.0^{\circ} \mathrm{C}$ and the maximum $26.0^{\circ} \mathrm{C}$. Salinity minimum was 10.17 psu and the maximum 38.90 psu. Out of 31 samplings conducted in the research area, eight were taken during rainfall (maximum $8.3 \mathrm{~mm}$ daily) and one after a snowfall (January 2017, $1.4 \mathrm{~mm}$ ).

\subsection{Station P-1 / Postaja P-1}

Seven samplings were made, one immediately following a rainfall (April 2016), and one after a snowfall (January 2017). A low density of heterotrophic bacteria $\left(0.131-0.627 \times 10^{6} \mathrm{~mL}^{-1}\right)$ obtained by a direct method characterized the researched coastal area as oligotrophic [19]. The maximum values occurred only twice, following rain and snowfall. The total number of

Table 3 Correlation of parameters (Station P-2)

Tablica 3. Korelacije istraživanih parametara (postaja P-2)

\begin{tabular}{|c|c|c|c|c|c|c|c|c|c|c|}
\hline & TEMP & $\mathrm{KO}$ & ST & SAL & $\mathrm{BACT}$ & $\mathrm{TC}$ & FC & FS & $\mathrm{R} 2 \mathrm{a}$ & MPN \\
\hline TEMP & 1,00 & & & & & & & & & \\
\hline $\mathrm{KO}$ & & 1,00 & & & & & & & & \\
\hline ST & 0,94 & & 1,00 & & & & & & & \\
\hline SAL & $-0,20$ & & $-0,22$ & 1,00 & & & & & & \\
\hline BACT & 0,79 & & 0,69 & $-0,72$ & 1,00 & & & & & \\
\hline $\mathrm{TC}$ & 0,38 & & 0,66 & $-0,46$ & 0,35 & 1,00 & & & & \\
\hline FC & 0,31 & & 0,62 & 0,02 & $-0,00$ & 0,87 & 1,00 & & & \\
\hline FS & 0,53 & & 0,77 & 0,15 & 0,10 & 0,77 & 0,95 & 1,00 & & \\
\hline $\mathrm{R} 2 \mathrm{a}$ & 0,06 & & 0,33 & 0,50 & $-0,43$ & 0,53 & 0,87 & 0,85 & 1,00 & \\
\hline MPN & 0,78 & & 0,95 & $-0,13$ & 0,47 & 0,81 & 0,84 & 0,93 & 0,59 & 1,00 \\
\hline
\end{tabular}

Correlation values between parameters measured. Station-2

Correlation are statistically significant $\mathrm{P}<0,01\left(^{* *}\right)$ and $\mathrm{P}<0,05\left(^{*}\right)$.

TEMP, air temperature; KO, daily rainfall; ST sea temperature; SAL, salinity; BACT, bacterioplankton ; TC, total coliforms; FC, faecal coliforms; FS, faecal streptococci; R2a viable heterotrophic bacteria; MPN mussells E.coli. 


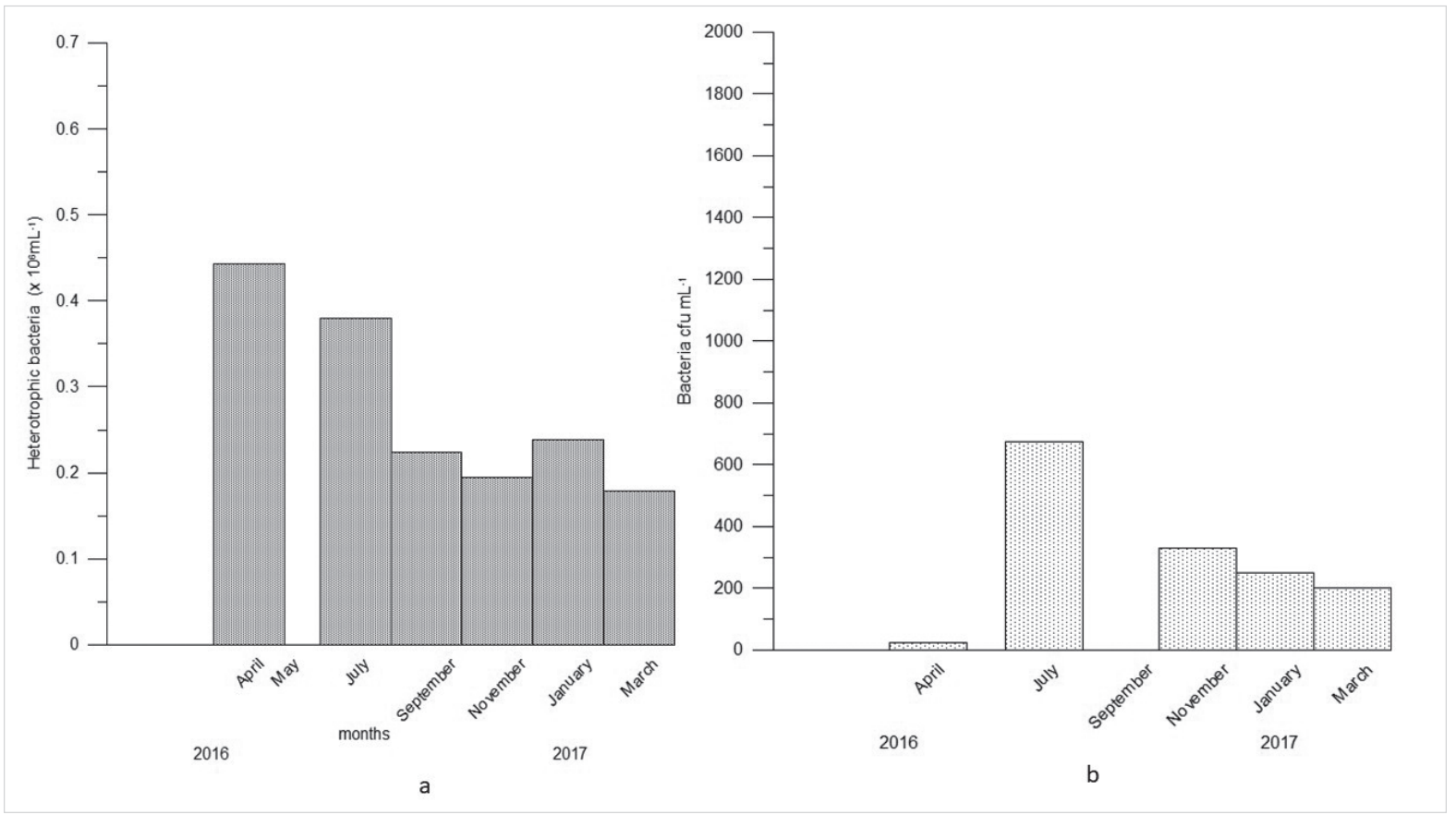

Figure 5 Heterotrophic bacterial abundances in the water (Station P-2): a) total - epifluorescent microscopy method, b) culturable - Spread Plate Method

Slika 5. Broj heterotrofnih bakterija u uzorcima morske vode (postaja P-1): a) ukupni broj metodom epifluorescentne mikroskopije, b) broj kolonija metodom širenja razmaza

heterotrophic bacteria in water following precipitation is up to twice that recorded in dry period (Figure 2 a). A correlation of heterotrophic bacteria to rainfall has been noticed (Table 2) which suggests the influence of long term retention of rainfall waters in the harbour. Bacterial counts obtained from spreading on R2A agar plate, compared to the epifluorescence method, differ by $0.007-0.358 \%$ (Figure $2 \mathrm{a}$, b). Significant correlation with faecal coliforms and streptococci has been established,

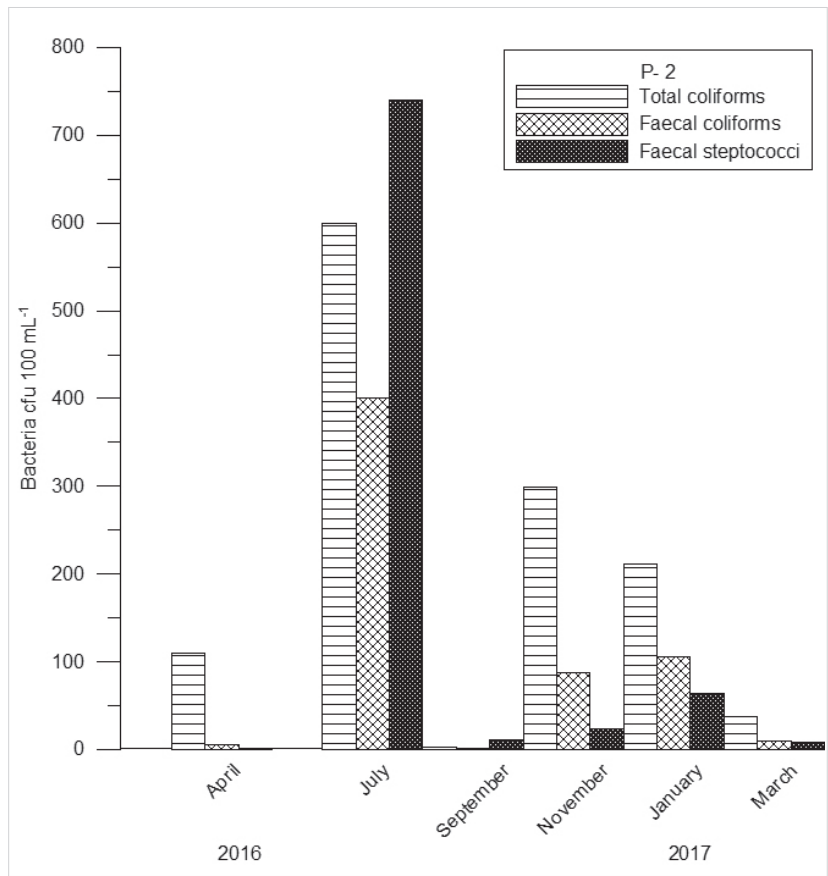

Figure 6 Results of total, faecal coliforms and faecal streptococci counts in the water samples (Station P-2) Slika 6. Broj ukupnih i fekalnih koliforma i fekalnih streptokoka u morskoj vodi (postaja P-2) while there is only a marginally significant relation with rainfall (Table 2). Sanitary quality indicator counts immediately increase following rainfall. Bacterial counts show a seasonal aspect with the lowest values during early spring and highest immediately following rainfall (Figure 3). With all samplings there is significant correlation between the numbers of faecal coliforms and the amount of rainfall $(p<0.01)$. Also, a significant correlation is shown for total and faecal coliforms and faecal streptococci

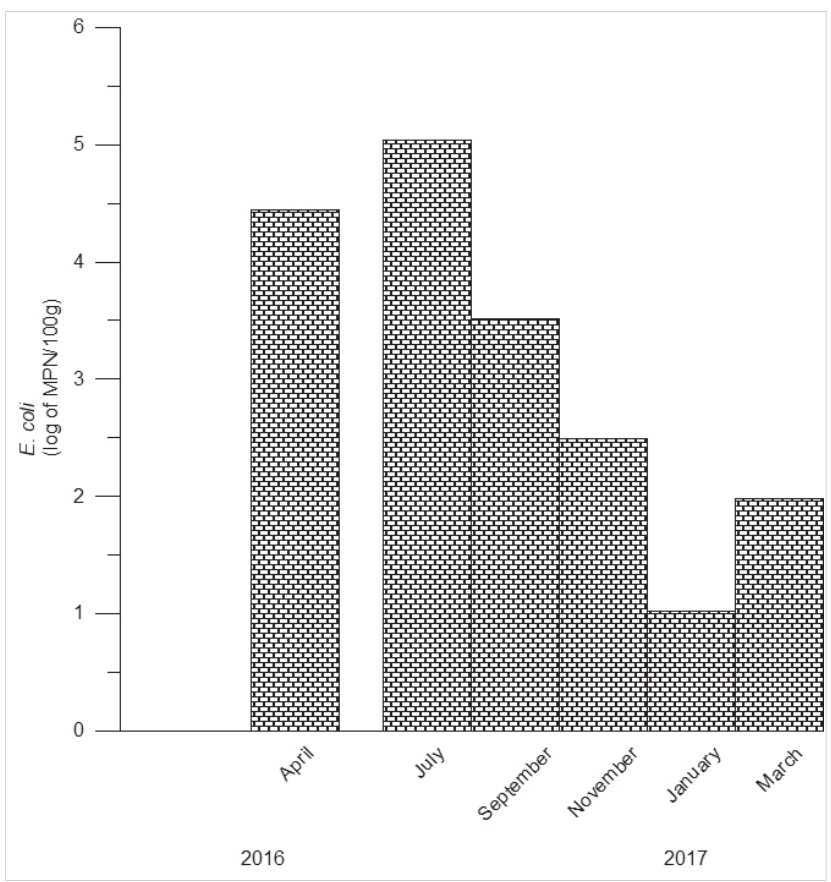

Figure 7 Concentration of E. coli in the mussel samples (Station P-2) Slika 7. Koncentracija E. coli u tkivu školjkaša (postaja P-2) 


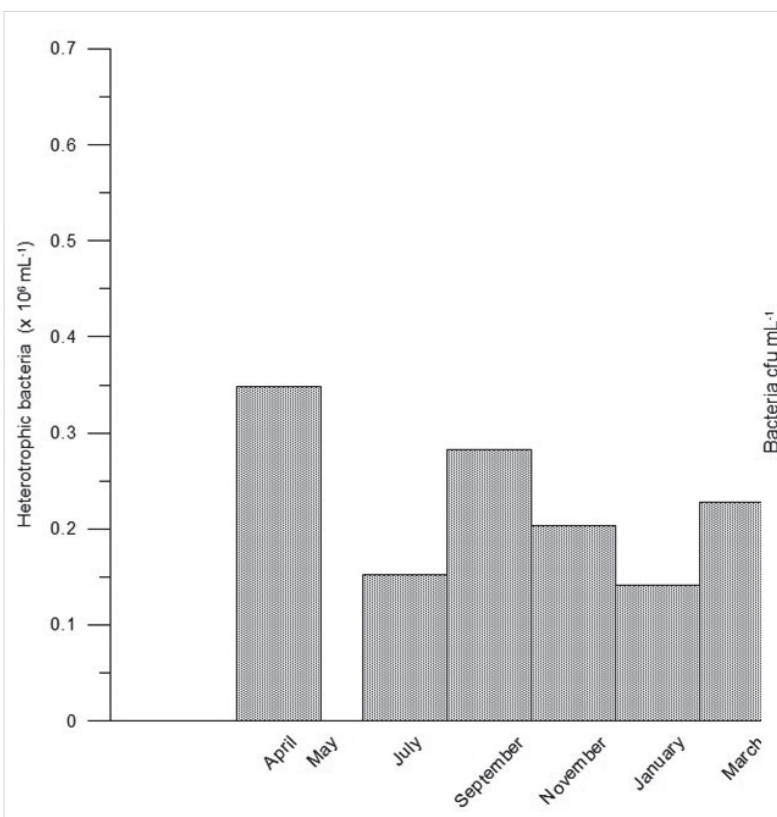

2016

2017

a

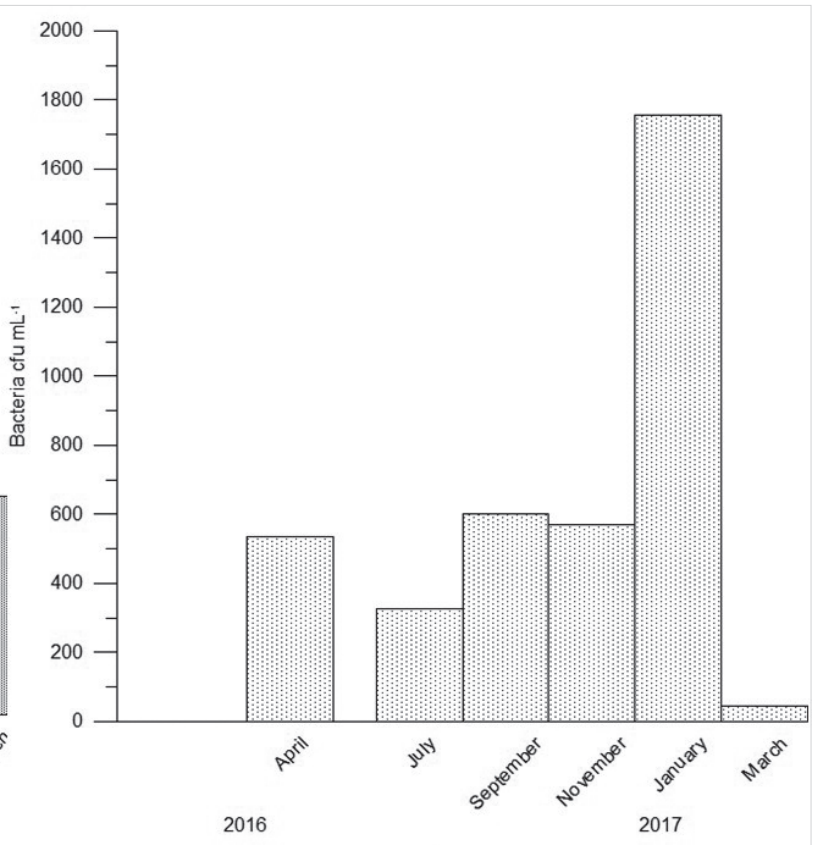

b

Figure 8 Heterotrophic bacterial abundances in the water (Station P-3): a) total - epifluorescent microscopy method, b) culturable - Spread Plate Method

Slika 8. Broj heterotrofnih bakterija u uzorcima morske vode (postaja P-3): a) ukupni broj metodom epifluorescentne mikroskopije, b) broj kolonija metodom širenja razmaza

$(p<0.05)$. The significant correlation $(p<0.01)$ between heterotrophic bacteria obtained on R2a and faecal streptococci and coliforms indicates their origin from rainfall waters and wastewater outlets (Table 2). The highest value of EC in FIL was recorded following rainfall (Figure 4). E. coli concentration counts in mussel several days before and immediately after rainfall differ by factor of 1,739 . Difference in bacterial counts between samplings was not statistically significant $(p>0.05)$.

\subsection{Station P-2 / Postaja P-2}

Six samplings were conducted, none of which were during rainfall. Low heterotrophic bacteria values obtained using a direct method $\left(0.179-0.443 \times 10^{6} \mathrm{~mL}^{-1}\right)$ characterize the investigated area as oligotrophic (Figure 5 a) [19]. Bacterial counts obtained by spreading on R2a agar plates compared to total bacterial counts using epifluorescence differ by $0.006-$
$0.178 \%$ (Figure $5 \mathrm{a}, \mathrm{b}$ ). Maximum values for water sanitary quality indicators were noted for July 2016 (TC 600 CFU $100 \mathrm{~mL}^{-1}$, FC $400 \mathrm{CFU} 100 \mathrm{~mL}^{-1}$ and FS $400 \mathrm{CFU} 100 \mathrm{~mL}^{-1}$ ) (Figure 6). The highest value of concentration $\mathrm{EC}$ in mussel tissues was recorded in July 2016 (Figure 7). All sanitary indicators exhibited maximal increase during the summer (July 2016) (Figure 6, Figure 7). There was no significant correlation between parameters (Table 3 ).

\subsection{Station P-3 / Postaja P-3}

Six samplings were performed, once immediately following rainfall (November). The abundance of heterotrophic bacteria obtained by the direct method were within values of $10^{5} \mathrm{~mL}^{-1}(0.141-0.348$ $\left.x 10^{6} \mathrm{~mL}^{-1}\right)$, fairly low for coastal waters, which characterized it as oligotrophic (Figure 8 a) [19]. Bacterial count using spreading over R2a agar, compared to total bacterial numbers using epifluorescence method differed by $0.019-1.245 \%$ (Figure $8 \mathrm{a}$, b).

Table 4 Correlation of parameters (Station P-3)

Tablica 4. Korelacije istraživanih parametara (postaja P-3)

\begin{tabular}{|c|c|c|c|c|c|c|c|c|c|c|}
\hline & TEMP & $\mathrm{KO}$ & ST & SAL & ACT & $\mathrm{TC}$ & $\mathrm{FC}$ & FS & $\mathrm{R} 2 \mathrm{a}$ & MPN \\
\hline TEMP & 1,00 & & & & & & & & & \\
\hline $\mathrm{KO}$ & 0,13 & 1,00 & & & & & & & & \\
\hline ST & 0,58 & $-0,15$ & 1,00 & & & & & & & \\
\hline SAL & 0,46 & $-0,23$ & 0,28 & 1,00 & & & & & & \\
\hline BACT & 0,50 & $-0,13$ & 0,09 & 0,45 & 1,00 & & & & & \\
\hline TC & 0,61 & 0,22 & 0,77 & $-0,15$ & 0,27 & 1,00 & & & & \\
\hline FC & $-0,39$ & 0,18 & $-0,95^{* *}$ & $-0,16$ & 0,21 & $-0,64$ & 1,00 & & & \\
\hline FS & 0,60 & $-0,30$ & $0,98^{* *}$ & 0,35 & 0,20 & 0,73 & $-0,91 *$ & 1,00 & & \\
\hline $\mathrm{R} 2 \mathrm{a}$ & $-0,56$ & 0,13 & $-0,03$ & $-0,73$ & $-0,15$ & 0,29 & $-0,01$ & $-0,08$ & 1,00 & \\
\hline MPN & 0,66 & $-0,52$ & 0,27 & 0,26 & 0,41 & 0,22 & $-0,17$ & 0,40 & $-0,56$ & 1,00 \\
\hline
\end{tabular}

Correlation values between parameters measured. Station-3

Correlation are statistically significant $\mathrm{P}<0,01\left(^{* *}\right)$ and $\mathrm{P}<0,05\left(^{*}\right)$.

TEMP, air temperature; KO, daily rainfall; ST sea temperature; SAL, salinity; BACT, bacterioplankton ; TC, total coliforms; FC, faecal coliforms; FS, faecal streptococci; R2a viable heterotrophic bacteria; MPN mussells E.coli. 


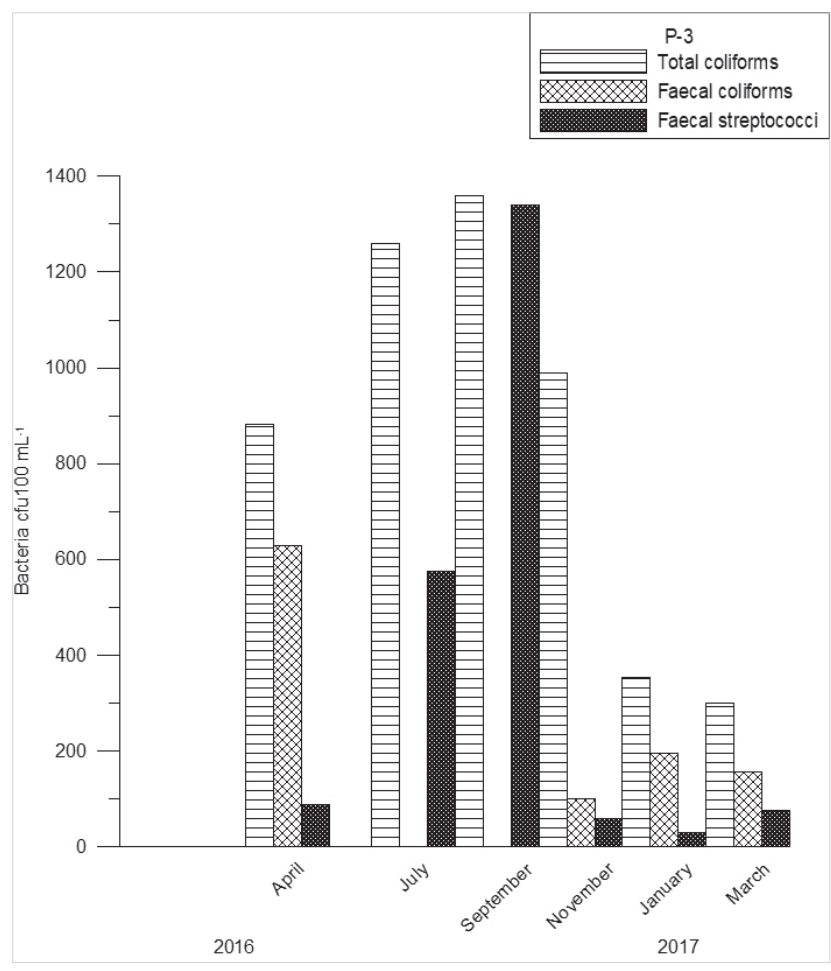

Figure 9 Results of total, faecal coliforms and faecal streptococci counts in the water samples (Station P-3) Slika 9. Broj ukupnih i fekalnih koliforma i fekalnih streptokoka u morskoj vodi (postaja P-3)

The maximum values of TC (1360 CFU $\left.100 \mathrm{~mL}^{-1}\right)$ and FS (1340 CFU $100 \mathrm{~mL}^{-1}$ ) were recorded in September 2016. Maximum values of FC (630 CFU $100 \mathrm{~mL}^{-1}$ ) were in April; for July and September 2016, and for January 2017 were recorded low values (Figure 9). The value of EC in mussel tissues increased in spring and summer (Figure 10). The significant correlation $(p<0.01)$ were between sea water temperature and FC and FS. Also, a significant correlation is shown for total and faecal coliforms and faecal streptococci $(p<0.05)$ (Table 4).

\subsection{Station P-4 / Postaja P-4}

Six samplings were made, one immediately following rainfall (November). The abundance of heterotrophic bacteria obtained by the direct method were within values of $10^{5} \mathrm{~mL}^{-1}$ (0.138-0.460 $\left.\times 10^{6} \mathrm{~mL}^{-1}\right)$, fairly low for coastal waters, which

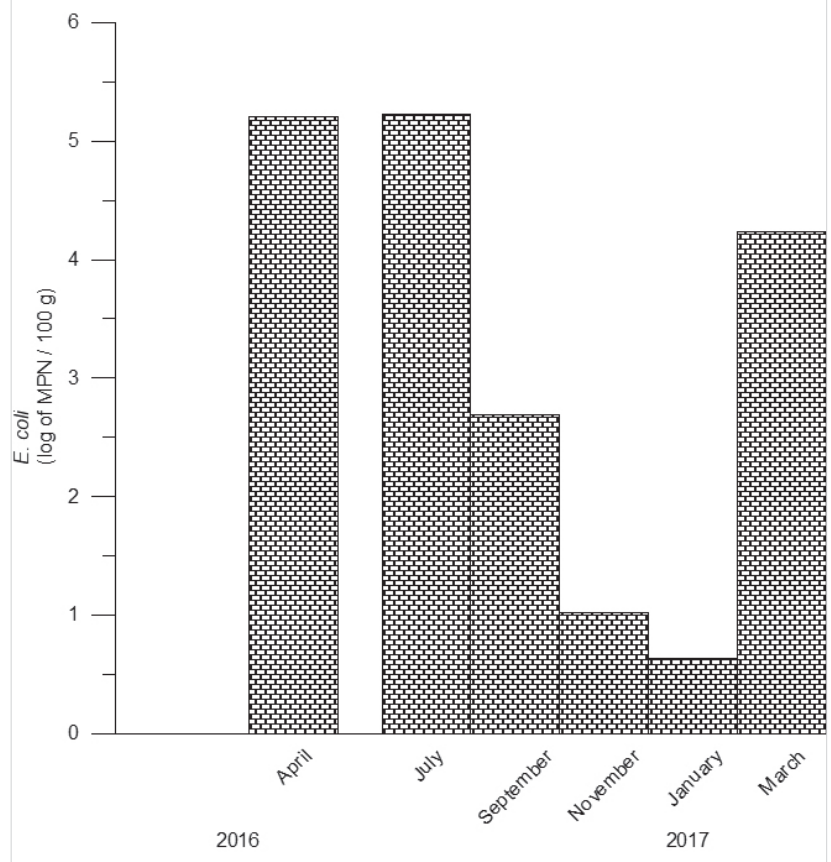

Figure 10 Concentration of $E$. coli in the mussel samples (Station P-3)

Slika 10. Koncentracija E. coli u tkivu školjkaša (postaja P-3)

characterizes it as oligotrophic (Figure 11 a) [19]. Bacterial count using spreading over R2a agar plate, compared to total bacterial numbers using epifluorescence method differed by $0.077-0.528 \%$ (Figure $11 \mathrm{a}, \mathrm{b}$ ). Maximum values of TC (1920 CFU $100 \mathrm{~mL}^{-1}$ ) were recorded in September 2016, FC in April 2016 (252 CFU $100 \mathrm{~mL}^{-1}$ ) and FS (390 CFU $100 \mathrm{~mL}^{-1}$ ) in November 2016. The low values FS were in April 2016 and January 2017 (Figure 12). The value of EC in mussel tissues showed maximum in April and July 2016 and minimum in January 2017 (Figure 13). No significant correlation between parameters was recorded (Table 5).

\subsection{Station P-5 / Postaja P-5}

Six samplings were made, two immediately following rainfall (September 2016 and November 2016). Low abundances of

Table 5 Correlation of parameters (Station P-4)

Tablica 5. Korelacije istraživanih parametara (postaja P-4)

\begin{tabular}{|c|c|c|c|c|c|c|c|c|c|c|}
\hline & TEMP & KO & ST & SAL & BACT & TC & FC & FS & $\mathrm{R} 2 \mathrm{a}$ & MPN \\
\hline TEMP & 1,00 & & & & & & & & & \\
\hline $\mathrm{KO}$ & 0,13 & 1,00 & & & & & & & & \\
\hline ST & 0,37 & 0,19 & 1,00 & & & & & & & \\
\hline SAL & 0,32 & $-0,28$ & 0,51 & 1,00 & & & & & & \\
\hline BACT & 0,06 & $-0,20$ & 0,37 & 0,27 & 1,00 & & & & & \\
\hline $\mathrm{TC}$ & 0,70 & 0,30 & 0,53 & 0,22 & 0,33 & 1,00 & & & & \\
\hline $\mathrm{FC}$ & $-0,38$ & 0,17 & $-0,14$ & $-0,43$ & 0,31 & $-0,57$ & 1,00 & & & \\
\hline FS & 0,42 & 0,52 & 0,37 & 0,13 & $-0,59$ & 0,48 & $-0,65$ & 1,00 & & \\
\hline $\mathrm{R} 2 \mathrm{a}$ & $-0,54$ & 0,51 & $-0,26$ & 0,22 & $-0,05$ & 0,09 & $-0,01$ & 0,10 & 1,00 & \\
\hline MPN & 0,76 & $-0,27$ & 0,17 & $-0,07$ & 0,50 & 0,72 & $-0,39$ & $-0,06$ & $-0,36$ & 1,00 \\
\hline
\end{tabular}

Correlation values between parameters measured. Station- 4

Correlation are statistically significant $\mathrm{P}<0,01\left(^{* *}\right)$ and $\mathrm{P}<0,05\left(^{*}\right)$.

TEMP, air temperature; KO, daily rainfall; ST sea temperature; SAL, salinity; BACT, bacterioplankton ; TC, total coliforms; FC, faecal coliforms; FS, faecal streptococci; R2a viable heterotrophic bacteria; MPN mussells E.coli. 

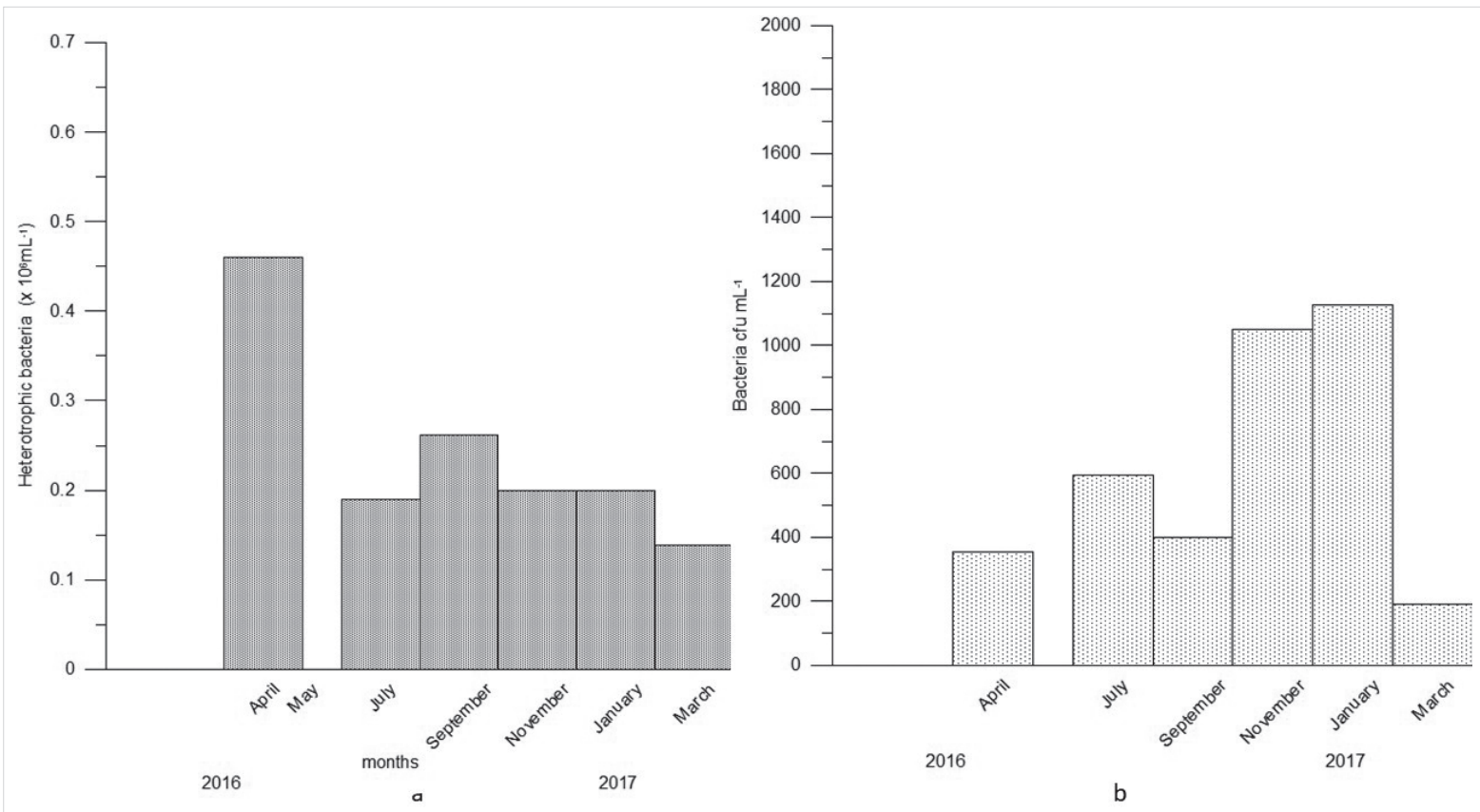

Figure 11 Heterotrophic bacterial abundances in the water (Station P-4): a) total - epifluorescent microscopy method, b) culturable - Spread Plate Method

Slika 11. Broj heterotrofnih bakterija u uzorcima morske vode (postaja P-4): a) ukupni broj metodom epifluorescentne mikroskopije, b) broj kolonija metodom širenja razmaza

heterotrophic bacteria obtained by direct method were within values of $10^{5} \mathrm{~mL}^{-1}\left(0.137-0.323 \times 10^{6} \mathrm{~mL}^{-1}\right)$, fairly low for coastal waters, which characterized it as oligotrophic (Figure 14 a) [19]. Creek water was tested twice, in January and March 2017 (Table 7). Bacterial count using spreading over R2a agar plate, compared to total bacterial numbers using epifluorescence method differed by $0.007-0.417 \%$ (Figure $14 \mathrm{a}, \mathrm{b}$ ). The maximum values of TC (465 CFU $100 \mathrm{~mL}^{-1}$ ) in November 2016, FC determined in May $2016\left(110 \mathrm{CFU} 100 \mathrm{~mL}^{-1}\right)$ as well as the FS (98 CFU $100 \mathrm{~mL}^{-1}$ ) in November 2016 immediately following rainfall (Figure 15). Of two samples of water from the creek discharging into the sea, (January 2017- after melting of snow and March 2017) exhibited increase over the standard level values of TC, FC and FS for drinking waters [25] (Table 7). The value of EC in mussel tissues showed an increase over the standard level [1] except for November 2016 and March 2017. Highest value of concentration of EC in tissue was recorded in January 2017
(Figure 16). The significant correlation were shown for total coliforms and daily rainfall $(p<0.01)$. Also, a significant negative correlation were shown for heterotrophic culturable bacteria and concentration of E. coli in musells ( $p<0.01$ ) (Table 6). Also, a significant correlation were negative shown for air temperature and faecal streptococci and heterotrophic culturable bacteria, positive correlation concentration E. coli in musells $(p<0.05)$

\subsection{Relational data for the research stations / Povezanosti podataka između istraživačkih postaja}

Pairwise T-test comparison of the bacterial counts for different sampling sites showed $(p<0,05)$ that there was a significant difference of means between sites P-5 and P-3 for FC $(t=2,276)$ and P-5 and P-4 for FS ( $t=2,727)$. All other groups of data showed no significant statistical difference. Total numbers of heterotrophic bacteria, culturable heterotrophic bacteria, total coliforms, faecal coliforms and faecal streptococci along the

Table 6 Correlation of parameters (Station P-5)

Tablica 6. Korelacije istraživanih parametara (postaja P-5)

\begin{tabular}{|c|c|c|c|c|c|c|c|c|c|c|}
\hline & TEMP & KO & ST & SAL & BACT & TC & FC & FS & $\mathrm{R} 2 \mathrm{a}$ & MPN \\
\hline TEMP & 1,00 & & & & & & & & & \\
\hline KO & $-0,48$ & 1,00 & & & & & & & & \\
\hline ST & 0,73 & 0,21 & 1,00 & & & & & & & \\
\hline SAL & 0,20 & 0,68 & 0,60 & 1,00 & & & & & & \\
\hline BACT & $-0,01$ & 0,02 & $-0,25$ & 0,44 & 1,00 & & & & & \\
\hline $\mathrm{TC}$ & $-0,42$ & $0,99 * *$ & 0,28 & 0,69 & $-0,03$ & 1,00 & & & & \\
\hline FC & $-0,88$ & 0,01 & $-0,94$ & $-0,58$ & 0,01 & $-0,05$ & 1,00 & & & \\
\hline FS & $-0,98 *$ & 0,46 & $-0,77$ & $-0,12$ & 0,21 & 0,39 & 0,87 & 1,00 & & \\
\hline $\mathrm{R} 2 \mathrm{a}$ & $-0,97^{*}$ & 0,31 & $-0,86$ & $-0,26$ & 0,20 & 0,24 & 0,94 & $0,99 *$ & 1,00 & \\
\hline MPN & $0,99 *$ & $-0,35$ & 0,82 & 0,29 & $-0,07$ & $-0,29$ & $-0,94$ & $-0,98^{*}$ & $-0,99 * *$ & 1,00 \\
\hline
\end{tabular}

Correlation values between parameters measured. Station-5

Correlation are statistically significant $\mathrm{P}<0,01\left(^{* *}\right)$ and $\mathrm{P}<0,05\left(^{*}\right)$.

TEMP, air temperature; KO, daily rainfall; ST sea temperature; SAL, salinity; BACT, bacterioplankton ; TC, total coliforms; FC, faecal coliforms; FS, faecal streptococci; R2a viable heterotrophic bacteria; MPN mussells E. coli. 


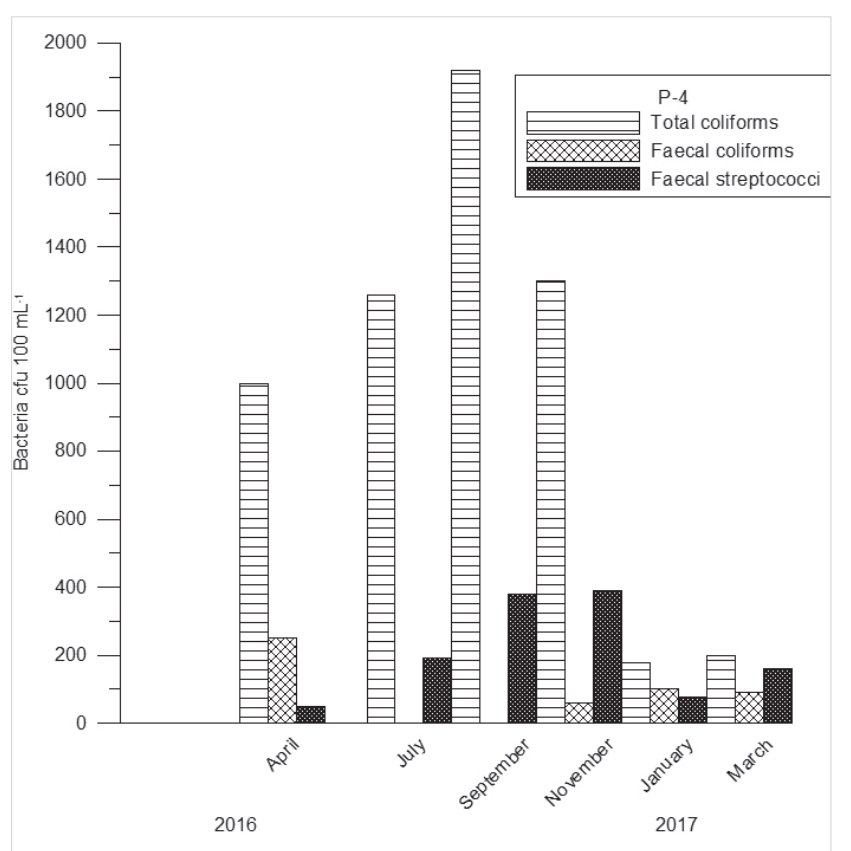

Figure 12 Results of total, faecal coliforms and faecal streptococci counts in the water samples (Station P-4) Slika 12. Broj ukupnih i fekalnih koliforma i fekalnih streptokoka u morskoj vodi (postaja P-4)

estuary between sampling stations $\mathrm{P}-3$ and $\mathrm{P}-4$ did not vary significantly (T-test, $\mathrm{p}>0.05$ ). Correlations between investigated parameters at researched stations are given in Table 8 .

\section{DISCUSSION / Rasprava}

The direct method of assessing density of heterotrophic bacteria for all sampling stations shows the characteristics of an oligotrophic area [19]. The variations among total heterotrophic bacteria numbers for each station were not found to be significant. The total number of total heterotrophic bacteria was not correlated with any other parameters. A discrepancy was recorded only for one station (P-1), close to the city sewer outfall following rainfall or snowfall. During heavy rainfall or surcharge of sewage waters there is an overflow to the city port. According to research in Norway [22] one additional complicating factor is precipitation in the form of snow, which will only bring land borne faecal material into the sea after thawing. Similar results of low heterotrophic bacterial counts were recorded previously in the river Ombla estuary [3] and in the bay of Gruž [38].

The direct microscopy method of counting includes all visible bacterial cells of which some could not form colonies on agar plate, or would take a long time to incubate, while the spreading on agar plate method, as traditionally used in microbiology, has its limits both in a qualitative and a quantitative sense because it yields counts of less than $1 \%$ of total bacterial numbers [29].

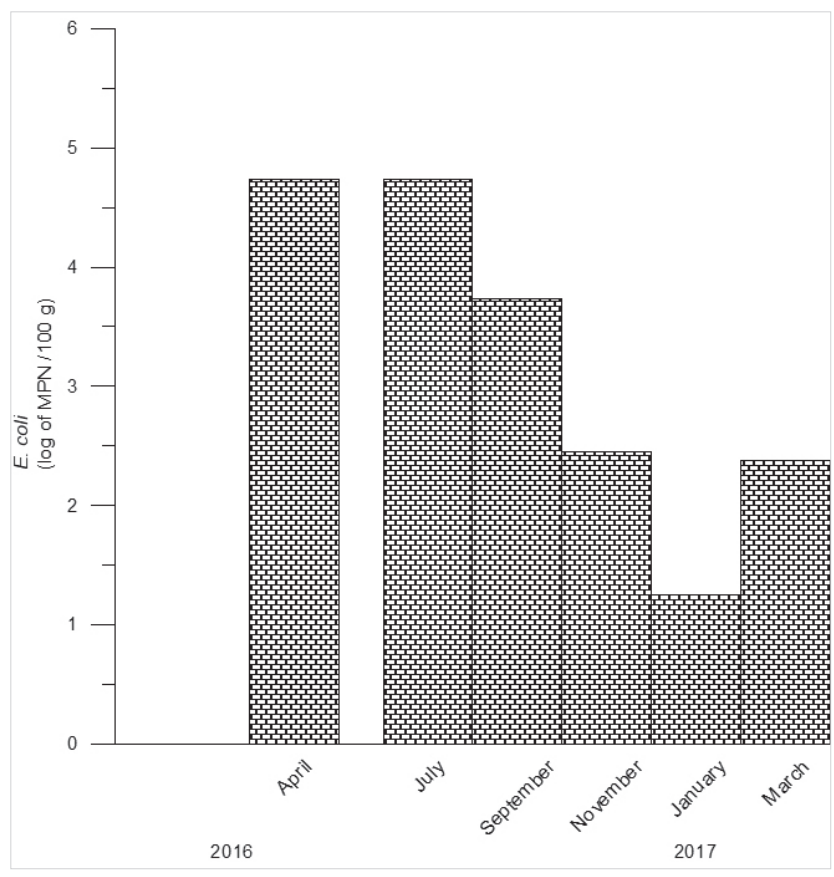

Figure 13 Concentration of E.coli in the mussel samples (Station P-4)

Slika 13. Koncentracija E.coli u tkivu školjkaša (postaja P-4)

Our results are generally in agreement in with the maximal percentage at station P-3, where is the highest influence of fresh water. The variation among total culturable heterotrophic bacteria numbers for each station ( $p>0.05$ ) was not found to be statistically significant, as has been recorded for the Black and Ionian Seas [2, 30]. At the Ombla estuary stations samples were taken above the pycnocline. The renewal time of the surface layer is estimated at about 1-2 hours during rain events and up to 8 hours during the dry season [5]. Due to the influence of freshwater, P-3 and P-4 stations in the Ombla estuary differ in total coliform counts compared to other stations in the research area. TC can, aside from faecal pollution, confirm an influx of greater quantities of sediment from land, particularly after rainfall [20].

Since 2004 sewage waters are collected through a pressurized pipeline into the main sewage system, instead of previous discharge directly into the Old City harbour. Seawater quality standards for recreational waters of the Republic of Croatia are determined on the basis of criteria defined by the regulation on Sea bathing water quality [24] in compliance with the standards of the European Union. According to the regulations for recreational water quality the seawater at the city harbour stations following rainfall does not qualify as recreational water. During heavy rainfall storms the drains are under-capacitated and rainwater overspill flows freely into the sea. Heavy rainfall additionally flushes the city streets and washes into the sea. At station P-5 the quality of seawater during

Table 7 Abiotic and microbial parameters measured in the creek Station P-5 (TC, total coliforms; FC, faecal coliforms; FS, faecal streptococci)

Tablica 7. Mikrobiološki i abiotički parametri analizirani u vodi potoka postaje P-5 (TC, ukupni koliformi; FC, fekalni koliformi; FS, fekalni streptokoki)

\begin{tabular}{|c|c|c|c|c|c|}
\hline Date & $\begin{array}{c}\text { Rainfall daily } \\
(\mathrm{mm})\end{array}$ & $\begin{array}{c}\text { TC } \\
(\mathrm{cfu} / \mathrm{ml})\end{array}$ & $\begin{array}{c}\text { FC } \\
(\mathrm{cfu} / \mathrm{ml})\end{array}$ & $\begin{array}{c}\text { FS } \\
(\mathrm{cfu} / \mathrm{ml})\end{array}$ & $\begin{array}{c}\text { Heterotrophic bacteria } \\
\left(10^{6} / \mathrm{ml}\right)\end{array}$ \\
\hline 16.01 .2017 & 10.1 & 1812 & 1764 & 776 & 0.217 \\
\hline 16.03 .2017 & 0 & 770 & 360 & 880 & 0.275 \\
\hline
\end{tabular}




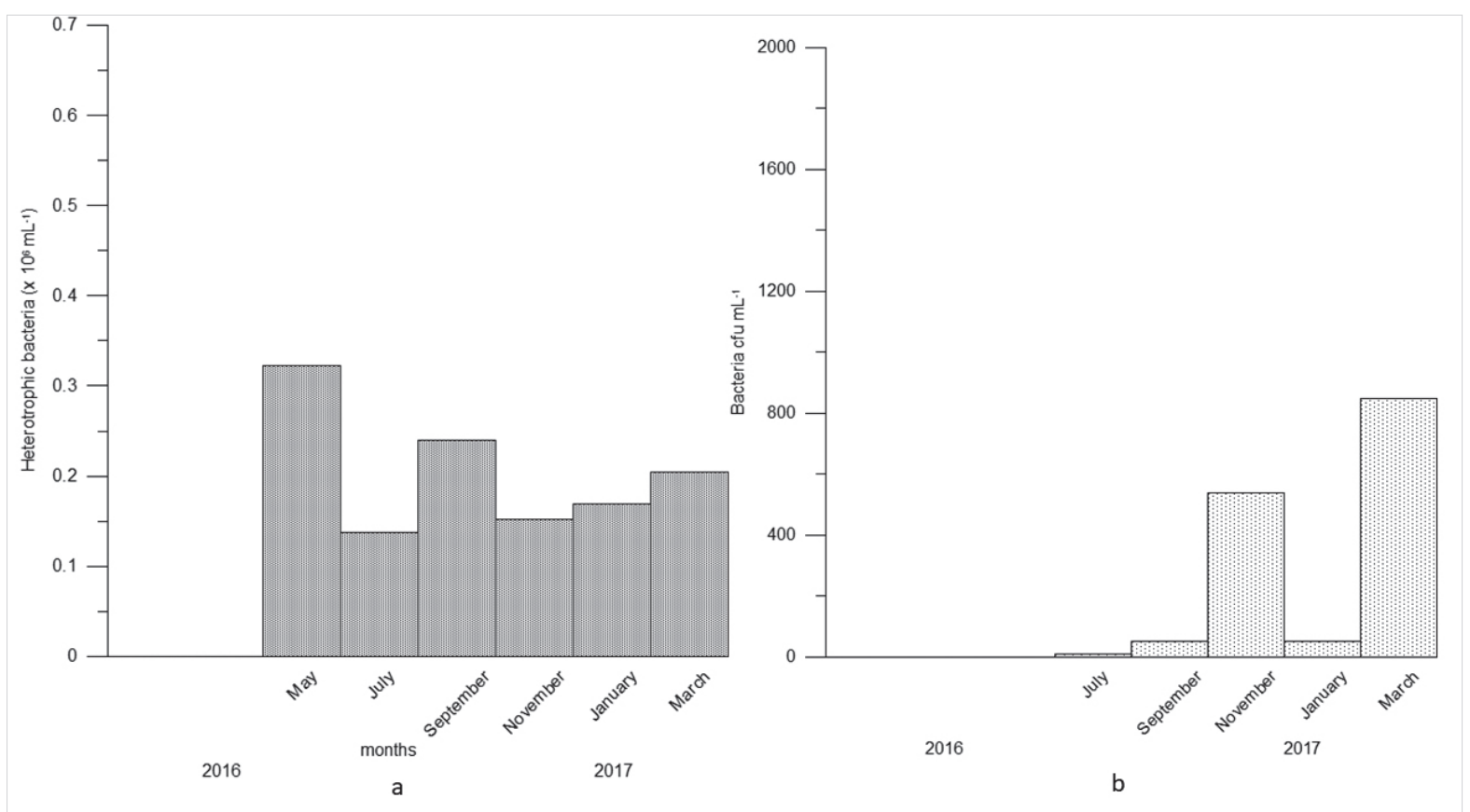

Figure 14 Heterotrophic bacterial abundances in the water (Station P-5): a) total - epifluorescent microscopy method, b) culturable - Spread Plate Method

Slika 14. Broj heterotrofnih bakterija u uzorcima morske vode (postaja P-5): a) ukupni broj metodom epifluorescentne mikroskopije, b) broj kolonija metodom širenja razmaza

the research period deviated from accepted standards only once, immediately following rainfall. In January 2017 indicators of faecal pollution were increased in the creek, probably due to the snow melting and the flushing of septic tanks. A second sampling, performed during a rainfall free period (March 2017), yielded increased results of faecal streptococci, indicating older faecal pollution [8].

According to research on the Salento Peninsula (Italy) [9] the level of faecal contamination found in mussels was on average about 10 to 100 times higher than that found in the water. On

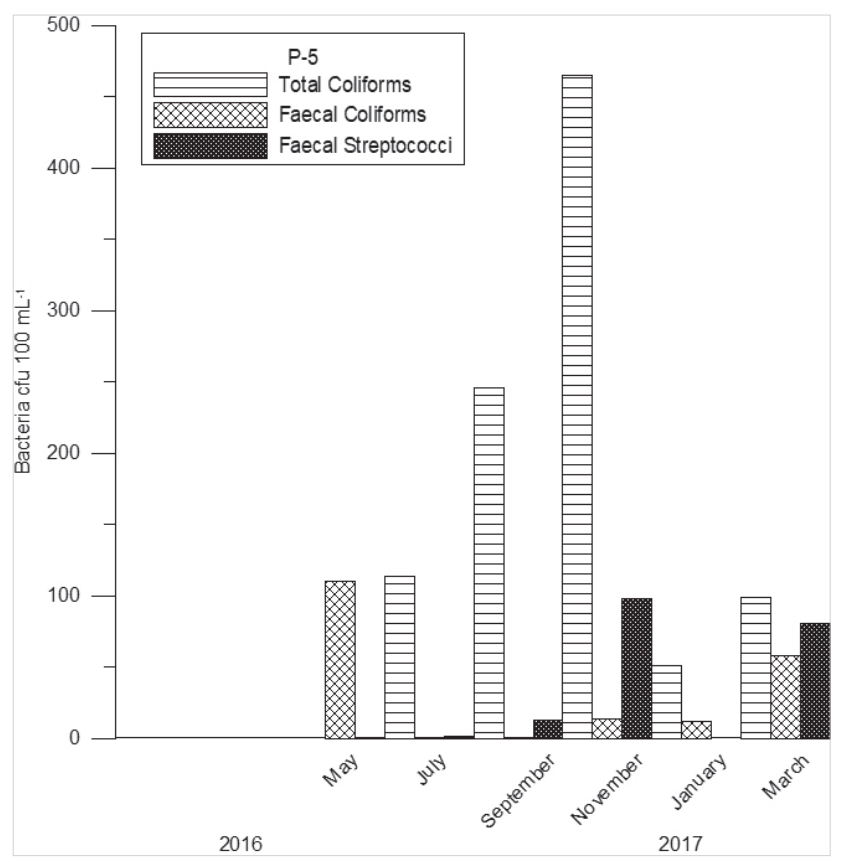

Figure 15 Results of total, faecal coliforms and faecal streptococci counts in the water samples (Station P-5)

Slika 15. Broj ukupnih i fekalnih koliforma i fekalnih streptokoka u morskoj vodi (postaja P-5) all investigated stations of the Dubrovnik area the results of microbiological analyses show that microbial concentrations were always higher within the mussels than in the surrounding waters. Pathogen and indicator bacteria can survive longer in bivalves than in seawater; moreover, they can reproduce [31]. The number of $E$. coli in mussel significantly correlated only with air temperature. Higher summer temperatures attract more people to the coast area: more people means a higher output of sewage material. Maximum E. coli concentrations in mussels and seawater were regularly recorded at all stations in

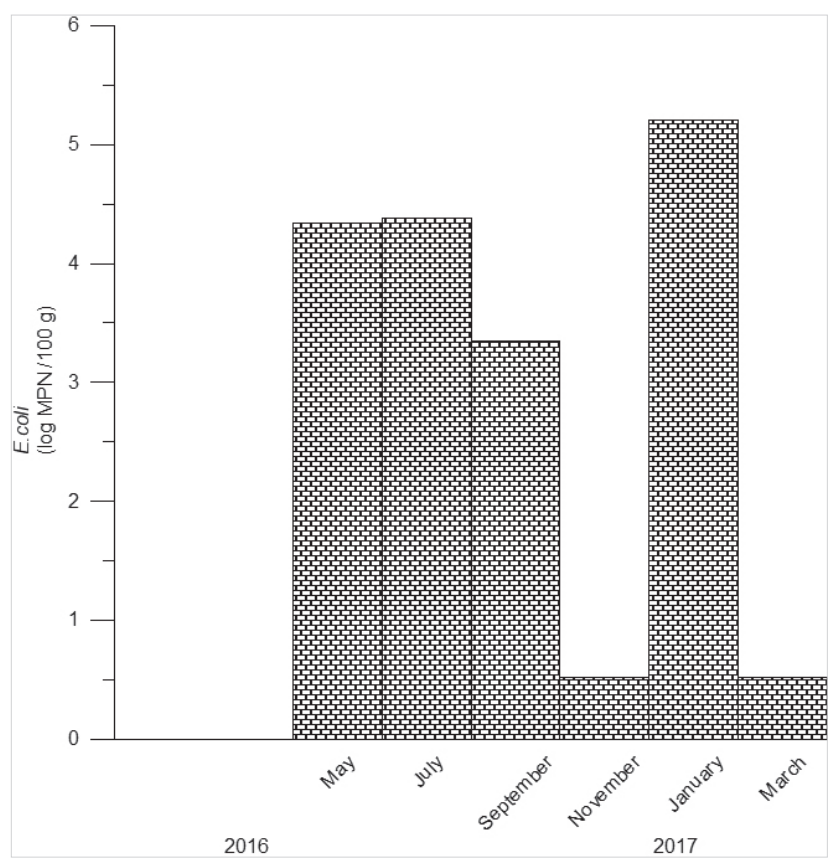

Figure 16 Concentration of E. coli in the mussel samples (Station P-5)

Slika 16. Koncentracija E. coli u tkivu školjkaša (postaja P-5) 
Table 8 Correlation of parameters between stations

Tablica 8. Korelacije istraživanih parametara među postajama

\begin{tabular}{|c|c|c|c|c|c|c|c|c|c|c|}
\hline & TEMP & KO & ST & SAL & BACT & TC & FC & FS & R2a & MPN \\
\hline TEMP & 1,00 & & & & & & & & & \\
\hline KO & 0,04 & 1,00 & & & & & & & & \\
\hline ST & $0,50 * *$ & 0,05 & 1,00 & & & & & & & \\
\hline SAL & 0,24 & $-0,07$ & 0,31 & 1,00 & & & & & & \\
\hline BACT & 0,00 & 0,13 & $-0,10$ & 0,19 & 1,00 & & & & & \\
\hline TC & 0,10 & 0,35 & 0,12 & $-0,43^{*}$ & 0,21 & 1,00 & & & & \\
\hline FC & $-0,18$ & 0,15 & $-0,10$ & $-0,53^{* *}$ & 0,20 & $0,60 * *$ & 1,00 & & & \\
\hline FS & 0,12 & 0,22 & 0,09 & $-0,29$ & 0,16 & $0,68 * *$ & $0,62 * *$ & 1,00 & & \\
\hline R2a & $-0,34$ & 0,30 & $-0,27$ & $-0,49 * *$ & 0,09 & $0,59 * *$ & $0,68 * *$ & $0,74^{* *}$ & 1,00 & \\
\hline MPN & $0,51^{* *}$ & $-0,23$ & 0,35 & $-0,03$ & 0,36 & $0,44^{*}$ & 0,12 & 0,23 & $-0,15$ & 1,00 \\
\hline
\end{tabular}

Corelation are statistically significant $\mathrm{P}<0,01\left({ }^{* *}\right)$ and $\mathrm{P}<0,05\left(^{*}\right)$.

TEMP, air temperature; KO, daily rainfall; ST, sea temperature; SAL, salinity; BACT, bacterioplankton ; TC, total coliforms; FC, faecal coliforms; FS, faecal streptococci; R2a, viable heterotrophic bacteria; MPN, mussells E.coli.

the summer, and minimum concentrations were recorded in the winter. This finding is in agreement with the results of previous environmental studies showing that bacterial cell numbers typically increase during the summer and when the temperature rises [31, 18, 9, 30, 22]. At the same concentration of $E$. coli in seawater, mussels concentrated more $E$. coli during winter than during the summer period, that is at lower temperature [31]. The variation between overall counting results for mussel samples taken from different sampling sites was not significant. In accordance with the results obtained from tidal estuary [16] relationships between $E$. coli and faecal coliform concentrations in shellfish and overlying water samples were relatively weak, a pattern often seen with data from uncontrolled environmental experiments. It was determined that faecal coliform counts in mussel samples were sometimes higher than legal limit values (Class A) [1] for all stations in the Dubrovnik coastal area. These results cover the summer season when the population of the investigated area is significantly increased owing to an influx of tourists (and the associated greater sewage outflow). The results obtained from this study can be of use to prevent potentially harmful adverse effects of microorganisms from polluted waters and shellfish. Shellfish products from this polluted environment should certainly not be consumed raw or undercooked [15, 12, 27].

Investigated stations of Dubrovnik area are located in coastal water, which is particularly influenced by climatic and anthropogenic factors interacting at the interface of land, freshwater, and seawater environments. Seasonal variables, such as rainfall and riverine network characteristics, determine the delivery of bacteria (including E. coli) to coastal water. Also, seasonal changes in the human population (increased in summer) can influence these parameters because the coastal area studied here has one of the highest tourist densities in Europe. Similar results have been observed in the North Adriatic where the same conditions apply [33].

Climate change contributes to local weather modifications, such as the frequency and intensity of storm events and heavy rainfall. Predictive models of climate change [21] have strongly suggested that extreme rainfall events will become more intense and frequent in the coming century [28]. During the $20^{\text {th }}$ century, under the influence of climate change, the annual trend of rainfall over the whole of Croatia is decreasing [10], which is similar to the trend over the broader Mediterranean area $[21,28]$. At the Dubrovnik station an average annual rainfall was $1,142 \mathrm{~mm}$ during the period of $1962-2012$ and 1,054.3 mm during 2016 (including an absolutely dry December) (data from Dubrovnik meteorological station for 1961-2018, Croatian Meteorological and Hydrological Service) In addition, in January of 2017 the first snow in eight years was recorded as well as the lowest air temperature, while the air temperature measured in 2016 for the Dubrovnik station was $1^{\circ} \mathrm{C}$ warmer than for the period 1961-1990 [10].

At the Dubrovnik urban area stations (P-1 and P-2) reconstruction and new regulations of the sewage system has improved the sanitary quality of seawater compared to earlier periods $[32,38]$. The lower overall microbiological quality of waters in the river Ombla estuary (stations P-3 and P-4) is likely to be the result of yet unfinished reconstruction of the local sewage system. The potential value of the present study is in its contribution of baseline information that should prove useful in planning the rational management of the Ombla. A general decrease of wet weather (decreased water flow) and more frequent extreme events associated with climate change are likely to lower river water quality even more, implying greater challenges for drinking water producers and suggesting the need for better control of sources of pollution. Increased values of indicators of faecal pollution in the extra-urban station P-5 (Trsteno) are probably the result of raining and snow melting, the flushing of septic tanks into the adjacent sea and the small creek discharging into the sea.

Results of this study indicate that major rainfall and snowfall events cause relatively high runoff volumes and high pathogen loadings to the sea which lead to shellfish contamination. In future it will be essential to evaluate the time needed for the recovery of water quality after an extreme contamination event.

\section{CONCLUSION / Zaključak}

This is the first intensive study conducted on the water and mussel quality of the coastal area of Dubrovnik. This study shows that it is important to note that microbial contamination has often been detected in mussels. The concentration in mussels is higher than the concentration in the ambient water, thus increasing the possibility of bacteria detection and detection of microbiological pollution that might have been missed by standard water-monitoring methods. The main factor affecting 
the total number of heterotrophic bacteria, total coliforms, faecal coliforms, faecal streptococci in the seawater and Escherichia coli in wild mussel (Mytilus galloprovincialis) is influx of substantial amounts of contaminated fresh water (sewage, river flow, creek and rainfall) into the coastal water. This should focus attention on the anthropogenic contamination especially in summer with its greatly increased influx of tourists (and the associated sewage outflow).

\section{REFERENCES / Literatura}

[1] Anon (2006 b) Council Directive 2006/113/EC of 12 December 2006 on the quality required of shellfish waters (codified version).Off. J. Eur. Communities L. Vol. 376. pp.14-20

[2] Berber, I., Avşar, C. (2014) Investigating Some Microbial Pollution Parameters of Seawater and Mussels (Mytilus galloprovincialis, Lamarck 1819) of Sinop Black Sea Coastal Zone, Turkey. Sains Malaysiana. Vol. 43. No 12. pp. 18351842. https://doi.org/10.17576/jsm-2014-4312-04

[3] Bobanović-Ćolić, S. (2011) Ekologija pikoplanktona u estuariju rijeke Omble. Disertacija, Sveučilište u Zagrebu.125 pp.

[4] Bonacci, O. (1995) Ground water behaviour in karst: example of the Ombla Spring (Croatia). Journal of Hydrology. Vol. 165. No 1-4. pp. 113-134. https:// doi.org/10.1016/0022-1694(94)02577-X

[5] Carić, M., Jasprica, N., Kršinić, F., Vilibić, l., Batistić, M. (2012) Hydrography, nutrients, and plankton along the longitudinal section of the Ombla Estuary (south-eastern Adriatic). Journal of the Marine Biological Association of the United Kingdom. Vol. 92. No 6. pp. 1227-1242. https://doi.org/10.1017/ S002531541100213X

[6] Cook, D. W. (1991) Indicators and alternate indicators of growing waters. In D. R. Ward \& C. H. Ackney (Ed.), Microbiology of marine food products. (pp. 19-39). Van Nostrand Reinhold, New York.

[7] Coulliette, A. D., Noble, R. T. (2008) Impacts of rainfall on the water quality of the Newport River Estuary (Eastern North Carolina, USA). Journal of Water and Health. Vol. 6. No 4. pp. 473-482. https://doi.org/10.2166/wh.2008.136

[8] Croatian Institute of Public Health (2015) Izvješće o zdravstvenoj ispravnosti vode za piće u Dubrovačko-neretvanskoj županiji za 2015. godinu. (in Croatian)

[9] De Donno, A., Liaci, D., Bagordo, F., Lugoli, F., Gabutti, G. (2008) Mytilus galloprovincialis as a Bioindicator of Microbiological Pollution of Coastal Waters: A Study Conducted in the Salento Peninsula (Italy). Journal of Coastal Research. Vol. 24. No 1A. pp. 216-221. https://doi.org/10.2112/05-0463.1

[10] DHMZ, (2013) Sixth National Communication of the Republic of Croatia under the United Nation Framework Convention on the Climate Change (UNFCCC) Selected sections in chapters: 7. Climate change impacts and adaptation measures 8. Resarch, systematic observation and monitoring. Zagreb 2013.

[11] Forsythe, S. J. (2010) The microbiology of safe food (2nd ed.). Chichester, UK: Wiley-Blackwell.

[12] Gillespie, I.A., Adak, G.K., O'Brien, S.J., Brett, M.M., BNolto, F.J. (2001) General outbreaks of infectiousintestinal disease associated with fish and shellfish, England and Wales, 1992-1999. Commun.Dis.Public Health. Vol. 4. No 2. pp. 117-123

[13] He, L.-M., He, Z.-L. (2008) Water quality prediction of marine recreational beaches receiving watershed baseflow and stormwater runoff in southern California, USA. Water Research. Vol. 42. No 10-11. pp. 2563- 2573. https://doi. org/10.1016/j.watres.2008.01.002

[14] Hobbie, J. E., Daley, R. J., Jasper, S. (1977) Use of Nucleopore filters for counting bacteria by fluorescence microscopy. Applied and Environmental Microbiology. Vol. 33. No 5. pp. 1225-1228. https://doi.org/10.1128/ aem.33.5.1225-1228.1977

[15] Kacar, A. (2011) Some microbial characteristics of mussels (Mytilus galloprovincialis) in coastal city area. Environmental Science and Pollution Research. Vol. 18. No 8. pp. 1384-1389. https://doi.org/10.1007/s11356-011-0487-3

[16] Kay, D., Kershaw, S., Lee, R., Wyer, M. D., Watkins, J., Francis, C. (2008) Results of field investigations into the impact of inermittent sewage discharges on the microbiological quality of wild mussels (Mytilus edulis) in a tidal estuary. Water Research. Vol. 42. No 2. pp. 3033-3046. https://doi.org/10.1016/j. watres.2008.03.020

[17] Kleinheinz, G. T., McDermott, C. M., Hughes, S., Brown, A. (2009) Effects of Rainfall on E. coli Concentrations at Door County,Wisconsin Beaches. International Journal of Microbiology.Vol. 2009. pp. 1-9. https://doi. org/10.1155/2009/876050
[18] Krstulović, N., Šolić, M. (1994) Bacteriological Quality of Eatable Mussels from the Sea of Split Area. Prehrambeno-tehnološka revija. Vol. 32. No 2-3. pp. 125-127

[19] Krstulović, N., Šolić, M., Marasović, I. (1997) Relationship between bacteria, phytoplankton and heterotrophic nanoflagellates along the trophic gradient. Helgoländer Meersuntersuchungen. Vol. 51. pp. 433-443.https://doi. org/10.1007/BF02908725

[20] Krstulović, N., Šolić, M. (2006) Mikrobiologija mora. Split. Institut za oceanografiju i ribarstvo. $317 \mathrm{pp}$.

[21] Lau, W. K. M., Wu, H.-T., Kim, K.-M. (2013) A canonical response of precipitation characteristics to global warming from CMIP5 models. Geophysical Research Letters. Vol. 40. No 12. pp. 3163-3169. https://doi.org/10.1002/grl.50420

[22] Lunestad, B.T., Frantzen, S., Svanevik, C.S., Roiha, I.S., Duinker, A. (2016) Time trends in the prevalence of Escherichia coli and enterococci in bivalves harvested in Norway during 2007-2012. Food Control. Vol. 60. pp. 289-295. https://doi.org/10.1016/j.foodcont.2015.08.001

[23] OJEU, (2006) Directive 2006/7/EC of the European Parliament and of the Council of 15 February 2006 oncerning the management of bathing water quality and repealing Directive 76/160/EEC. Official Journal of the European Union, Document 32006L0007, L 64/37. http://data.europa.eu/eli/dir/2006/7/oj

[24] Narodne novine (2008) Uredba o kakvoći mora za kupanje. Vol.73.

[25] Narodne novine (2013) Pravilnik o parametrima sukladnosti i metodama analize vode za ljudsku potrošnju. Vol. 125.

[26] Popis stanovništva, kućanstava i stanova 2011. Stanovništvo- tabele po naseljima. Zagreb. Republički zavod za statistiku.

[27] Potasman, I., Paz, A., Odeh, M. (2002) Infectious Outbreaks Associated with Bivalve Shellfish Consumption: A Worldwide Perspective. Clinical Infectious Diseases. Vol. 35. pp. 921-928. https://doi.org/10.1086/342330

[28] Riou, P., Le Saux, J. C., Dumas. F., Le Guyader. F. S., Le Goff, R., Maheux, F., Lamort, L., Pommepuy, M. (2008) The role of models in assessing the impact of sewage overflows on fecal water contamination. Resouce dokument. Journal of Shellfish Research. Open Access version: http://archimer.ifremer. fr/doc/00066/17739/.

[29] Simu, K., Holmfeldt, K., Zeifel, U. L., Hagstrom, A. (2005) Culturability and Coexistence of Colony-Forming and Single-Cell Marine Bacterioplankton. Applied and Environmental Microbiology. Vol. 71. No 8. pp. 4793-4800. https://doi.org/10.1128/AEM.71.8.4793-4800.2005

[30] Stabili, L., Acquaviva, M. I., Cavallo, R. A. (2005) Mytilus galloprovincialis filter feeding on the bacterial communityin a Mediterranean coastal area (Northern Ionian Sea, Italy). Water Research. Vol. 39. No 2-3. pp. 469-477. https://doi.org/10.1016/j.watres.2004.10.010

[31] Šolić, M., Krstulović, N., Jozić, S., Curać, D. (1999) The rate of concentration of faecal coliforms in shellifish under different environmental conditions. Environmental International. Vol. 25. No 8. pp. 991-1000. https://doi. org/10.1016/S0160-4120(99)00067-7

[32] Šoša, I., Radoničić, S. (1990) Medicinski aspekti i sanitarna kontrola kvalitete mora u turističkoj sezoni 1988. godine na području Dubrovnika. Pomorska medicina. Vol. 39. pp. 505-508

[33] Tabanelli, G., Montanari, C., Gardini, A., Maffel, M., Prioli, C., Gardini, F. (2017) Environmental Factors Affecting Escherichia coli Concentrations in Striped Venus Clam (Chamelea gallina L.) Harvested in the North Adriatic Sea. Journal of Food Protection. Vol. 80. No 9. pp. 1429-1435. https://doi. org/10.4315/0362-028X.JFP-17-058

[34] UNEP/WHO (United Nations Environment Programme/World Health Organization). (1983a) Determination of total coliforms in seawater by membrane filtration culture method. Reference Methods for Marine Pollution Studies. No 2. Rev. I. Geneva, UNEP/WHO.

[35] UNEP/WHO (United Nations Environment Programme/World Health Organization). (1983b) Determination of faecal coliforms in seawater by membrane filtration culture method. Reference Methods for Marine Pollution Studies. No 3. Rev. I. Geneva, UNEP/WHO.

[36] UNEP/WHO (United Nations Environment Programme/World Health Organization). (1983c) Determination of faecal streptococci in seawater by membrane filtration culture method. Reference Methods for Marine Pollution Studies. No 4. Rev. I. Geneva, UNEP/WHO.

[37] UNEP/WHO (United Nations Environment Programme/World Health Organization). (1983d) Determination of faecal coliforms in bivalves by multiple test tube method. Reference Methods for Marine Pollution Studies. No 5. Rev. 1. Geneva, UNEP/WHO.

[38] Viličić, D., Kršinić, F., Carić, M., Jasprica, N., Bobanović-Ćolić, S., Mikuš, J. (1995) Plankton and hydrography in a moderately eutrophic eastern Adriatic bay (Gruž Bay). Hydrobiologia. Vol. 304. No 1. pp. 9-22. https://doi.org/10.1007/ BF02530699 